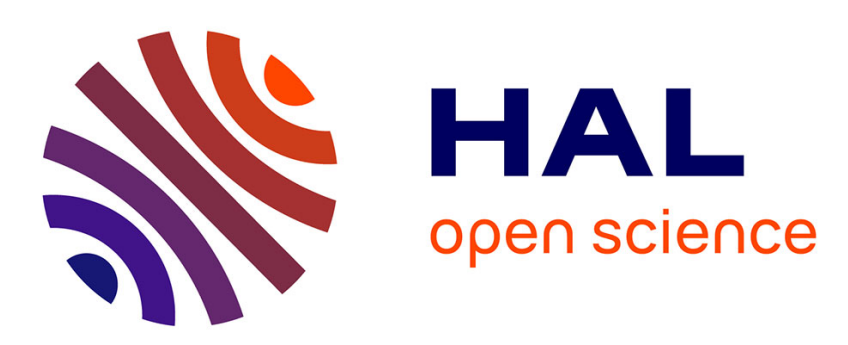

\title{
The impact of the European sovereign debt crisis on banks stocks. Some evidence of shift contagion in Europe
}

Jean-Pierre Allegret, Hélène Raymond, Houda Rharrabti

\section{- To cite this version:}

Jean-Pierre Allegret, Hélène Raymond, Houda Rharrabti. The impact of the European sovereign debt crisis on banks stocks. Some evidence of shift contagion in Europe. Journal of Banking and Finance, 2017, 74, pp.24 - 37. hal-01589269

\section{HAL Id: hal-01589269 \\ https://hal.science/hal-01589269}

Submitted on 15 May 2018

HAL is a multi-disciplinary open access archive for the deposit and dissemination of scientific research documents, whether they are published or not. The documents may come from teaching and research institutions in France or abroad, or from public or private research centers.
L'archive ouverte pluridisciplinaire HAL, est destinée au dépôt et à la diffusion de documents scientifiques de niveau recherche, publiés ou non, émanant des établissements d'enseignement et de recherche français ou étrangers, des laboratoires publics ou privés. 
The impact of the European sovereign debt crisis on banks stocks. Some evidence of shift contagion in Europe*

Jean-Pierre Allegret

EconomiX-CNRS, University of Paris Ouest, France.

Hélène Raymond

EconomiX-CNRS, University of Paris Ouest, France

Email: helene.raymond-feingold@u-paris10.fr

\title{
Houda Rharrabti
}

EconomiX-CNRS, University of Paris Ouest, France

Email: houdajad@hotmail.com

\begin{abstract}
This paper analyzes the influence of the recent European sovereign debt crisis on banks' equity returns for 15 countries. Our data span the period December 14th 2007 - March 8 2013 that encompasses several episodes of economic and financial turmoil since the collapse of the subprime credit market. Our contribution to the literature is twofold. First, we use an explicit multifactor model of equity returns extended with a sovereign risk factor. Second, we adopt a Smooth Transition Regression (STR) framework that allows for an endogenous definition of crisis periods and captures the changes in parameters associated with shift contagion. We find that the negative impact of the European sovereign debt crisis on banks' equity returns has been mostly confined to European banks, whereas U.S. banks appear to be unharmed by its direct impact and may even have benefited from it. Besides, we find some evidence of shift contagion across Europe.
\end{abstract}

Key words: Smooth Transition Regression model, European sovereign debt crisis, Banks' equity returns, Contagion, Interdependence.

JEL Code: E6; F3; G2

\footnotetext{
* The authors thank the two anonymous referees for their useful comments that helped to improve the paper. The usual disclaimer applies.
} 


\section{Introduction}

The 2007-2009 crisis began by intense tensions in the financial systems of advanced economies and unraveled into a dramatic contraction in global growth. To prevent a larger collapse in economic activity, governments and central banks intervened massively in order to support aggregate demand - via automatic stabilizers and discretionary expenditures - and to bailout financial institutions. As a result, public finance experienced a marked degradation ${ }^{1}$, leading to the emergence of the euro area sovereign debt crisis as a new phase of the global crisis. ${ }^{2}$ As the crisis worsened a growing concern arose about spillovers from sovereigns to banks, triggering a second round of spillovers from banks to sovereigns. Indeed, banks hold large amounts of government bonds to satisfy multiple purposes. First, investing in government bonds allows financial institutions to diversify their portfolio into low risk assets. The European prudential regulation has encouraged banks to hold such "safe" and liquid securities that may help to cushion losses on riskier assets. Second, holding government bonds is crucial for banks to access the central bank liquidity, insofar as the refinancing operations are based on highly rated securities. Besides, interbank loans and repos rely heavily on the use of public bonds as collaterals.

Caruana and Avdjiev (2012) identify various channels of transmission between banks and sovereigns. The transmission of financial sector risks to sovereigns that fuelled the Greek and eurozone sovereign debt crises from 2010 onwards rests on two main mechanisms. On the one hand, the deterioration in the balance sheets of financial institutions may cause a credit crunch that impinges on consumption and investment, and, in turn, spurs a slowdown in economic activity. As a result tax revenues decrease, leading to a deterioration in the fiscal situation of the state. On the other hand, the authorities may be in the obligation to support systematically important financial institutions against the threat of bankruptcy. Concerning the transmission of sovereign risks to the financial sector, Caruana and Avdjiev (2012) stress first the impact of banks' direct portfolio exposures in a context where the holding of government bonds is characterized by a strong home bias. Second, as sovereign bonds are used by banks as collaterals, a decrease in the quality of government debt may lead to a significant deterioration of funding conditions for financial institutions. A third channel of transmission from sovereigns to banks resides in the fact that a marked increase in sovereign credit risk may trigger doubts on the ability of the governments to offer a credible guarantee to banks and / or financial supports in case of distress. In other terms, a sovereign domestic debt crisis decreases the value of the explicit and implicit government guarantees that benefit banks that are considered too important to be allowed to fail (TITF). As these guarantees amount to very significant government subsidies (Schich and Lindh, 2012; IMF, 2014) their impairment may have a large negative impact on TITF banks' balance sheets. A first strand of the literature analyses contagion across sovereign bonds (yield spreads and / or CDS spreads). Mixed results emerge from this literature. For example, while Beirne and Fratzscher (2013) find some evidence of contagion, Caporin et al. (2013) conclude that the co-movements during extreme conditions do not exhibit any evidence of contagion. A second strand of the literature focuses on the

\footnotetext{
${ }^{1}$ In some countries such as Greece the deterioration in public finances was worsened by the crisis but had earlier roots.

2 For an overview, see Brender et al. (2013).
} 
influence of the financial sector on sovereign credit default swaps (CDS). Such a literature stresses the presence of a private-to-public risk transfer. More specifically, Acharya et al. (2014) find that in the prebailout period - that is before the announcement of the bailout in Ireland in late September 2008 - no clear relationship between bank and sovereign CDS is identified. The situation changes in the aftermath of the bailouts. In a similar way, Mody and Sandri (2012) consider that the nationalization of Anglo-Irish in January 2009 played a decisive role in the increase of the sensitivity of the sovereign's spread to the weakness of the financial sector. ${ }^{3}$ Gerlach et al. (2010) and Dieckmann and Plank (2012) conclude that the size of the domestic financial sector exerts an influence on the responses of the sovereign's spreads to financial tensions. A third strand of the literature finds that the quality of the sovereign debt influences the financial sector. For instance, Bolton and Jeanne (2011) show that the holding of sovereign bonds by banks tends to exacerbate contagion effects. Such effects are particularly important in a monetary union such as the eurozone, insofar as the integration of the banking system reduces the home bias that usually characterizes these holdings.

This paper contributes to the growing literature on the European sovereign debt crisis by focusing on the impact of European sovereign CDS on European and U.S. banks' equity returns over the period 2007-2013. Whereas most papers of the related literature do not rely on an explicit theoretical model of stock returns, we start from a variant of the multifactor model of Fama and French, extended by Carhart (1997), to control for the different channels of risk transmission to banks' stocks. More specifically, we modify the four-factor model of Carhart (1997) in three ways. First, we add the sovereign risk factor - proxied by the sovereign CDS - as an explanatory variable of banks' equity returns. Second, we control for the exchange rate risk. Third, we adopt a nonlinear specification to account for nonlinearities and, more specifically for the shift contagion (Forbes and Rigobon, 2001) that may contribute to the successive crisis episodes. So far the literature on the consequences of the European sovereign debt crisis for the banking sector has mainly captured these nonlinearities through dummy variables associated to crisis periods or to extreme events. In this paper, we use a Smooth Transition Regression (STR) framework that allows for an endogenous definition of crisis periods, smooth transitions and captures the shifts in parameters associated with shift contagion. We first choose the VSTOXX - the implied volatility of the Eurostoxx50 - as the transition variable insofar as it captures the rise in the European stock market's volatility associated with crisis episodes in the eurozone. As robustness tests and to gain further insight into the economic and financial variables that may trigger contagion we also use two alternative transition variables: the iTraxx Financials index and the lagged stock return of the banking sector. Using daily data from December 14, 2007 to March 8, 2013, we estimate three variants of our STR model, associated with the three aforementioned transition variables, for a sample of thirteen European countries, including two non-members of the eurozone (the United Kingdom and Switzerland), and two non-European countries (Japan and the U.S). The studied period encompasses four episodes of crises, namely: the subprime crisis of 2007/2008, followed by the global crisis

\footnotetext{
${ }^{3}$ The authors show that the failure of Bear Stearns in March 2008 has been a first turning point.
} 
after the failure of Lehman Brothers, then in October 2009 the Greek crisis ${ }^{4}$, followed by the eurozone sovereign debt crisis in 2010-2012. ${ }^{5}$ Whereas an extensive literature considers the sovereign risks of GIIPS countries - e.g. Greece, Ireland, Italy, Portugal, and Spain - we focus on Greece, Ireland, and Portugal (GIP). Indeed, we are particularly interested to see to what extent "small" economies (GIP represent less than $9 \%$ of the general government debt of the eurozone) lead to contagion effects.

Our major findings are twofold. First, our results suggest that the direct negative impact of the European sovereign debt crisis on banks' equity returns has been mostly confined to European and Japanese banks. On the contrary, U.S. banks' equity returns did not negatively react to the rise in GIP sovereign CDS spreads and even appear to have benefited from it. Second, we find evidence of shift contagion outside GIP banks. The rest of this paper is organized as follows. Section 2 presents the main related literature. Section 3 introduces the model and the data used in the smooth transition regressions (STR). Section 4 analyzes the results and section 5 concludes.

\section{Related Literature}

Our paper is closely related to two strands of the existing literature. The first one investigates the interdependence between banks risks and sovereign risks. The second strand analyzes more specifically the extent of the contagion from the sovereign debt crisis to banks.

Alter and Schuler (2012) contribute to the first strand of the literature by estimating bivariate vector error correction and bivariate vector autoregressive models. They find that, while before the bailouts the sovereign CDS spreads only marginally affect the bank CDS spreads from the same country, their influence tends to become permanent in the period following the implementation of the bailout programs. Gross and Koky (2013) also explore the interdependencies across sovereign CDS spreads and bank CDS spreads but through a global vector autoregressive (GVAR) model. Their results suggest that sovereign-to-bank spillovers have been particularly intense in 2011-2012 when the euro area sovereign debt crisis was at its peak. Using panel estimations with cross-section fixed effects Arnold (2012) examines spillover of sovereign risk to the banking sector. Two results are especially interesting. First, an increase in the combined Sovereign CDS rates in GIPS exerts a negative influence on the banking sector risk (i.e. banks' CDS spreads increase and banks' stock returns fall). Second, banks heavily exposed to GIPS appear to be more strongly impacted by the increase in sovereign CDS spreads, but this result is mainly driven by banks originated from the GIPS. Chan-Lau et al. (2015) use fixed-effect panel regressions to investigate the impact of various measures of financial and economic conditions on banking equity returns. Their results show that sovereign risk approximated by the arithmetic average of the CDS spreads of GIIPS plus Belgium- increasingly explains equity returns in the banking sector after 2008. Bank-specific characteristics matter, as higher capitalization,

\footnotetext{
${ }^{4}$ On October 19 2009, the Greek Prime Minister mentions a possible debt default while on February 21 2012, the Greek second bailout program is ratified.

5 At the end of April 2010, we observe a wave of downgrades by rating agencies affecting Greece, Portugal, and Spain (from April 9 to April 28). On February 21 2012, the Greek second bailout programme is finalized leading to a suspension of Greek CDS.
} 
lower leverage and less reliance on wholesale funding improve the resilience of banks (equity returns). In addition, they identify a regional effect as the European debt crisis affects more the banks in Europe (including banks in the U.K.) than banks located in other regions. Acharya and Steffen (2015) investigate the sensitivity of banks' equity returns to sovereign bond returns. Using various econometric methods, they show that banks from eurozone and non-eurozone countries embark on carry trade operations by financing long term peripheral bonds holding with short term debt. As a result, they increase their vulnerability to a sovereign debt crisis. In addition, the authors identify evidence showing that moral hazard and regulatory arbitrage matter to explain banks behavior. Whereas the previous studies are mainly based on CDS data and when they use data on banks stocks do not rely on an explicit model of stock returns, Poirson and Schmittman (2013) estimate a variant of the world Capital Asset Pricing Model (CAPM) with a countryspecific factor. The results suggest that the sensitivity of banks to global factors ( $\beta$ of the global factor) increases in times of strong market volatility: in 2008-2009 in the aftermath of Lehman Brothers collapse and in 2011 with the European debt crisis.

The second strand of the relevant literature investigates more directly contagion effects from sovereign debt crises to the banking sector. De Bruyckere et al. (2013) define contagion as "excess correlation", that is to say a correlation over and above that resulting from economic fundamentals. Starting from this definition, their main aim is twofold. On the one hand, they estimate a factor model to identify the presence of contagion effects between banks and countries of the eurozone. On the other hand, they investigate whether bank- and country-specific characteristics drive the excess correlation. Their study leads to three major findings. First, they identify significant evidence of contagion between banks and sovereigns CDS spreads during the European debt crisis. Second, as banks' government exposures exhibit home bias, they show that contagion effects are stronger between banks and their home country. Third, as in previous studies, the intensity of contagion is influenced by bank-specific characteristics. Alter and Beyer (2014) quantify the sovereign-banks feedback loop by estimating a vector autoregressive model with exogenous variables (VARX). They find an upward trend concerning contagion. In periods of stress, the feedback loop intensifies. Finally, the results for the shocks on Spanish sovereign CDS spread suggest that "non-core" countries (Greece, Ireland, Italy, and Portugal) are more sensitive than "core" countries (Austria, Belgium, Finland, France, Germany, and the Netherlands), but the difference between these groups decreases during times of distress. Contrary to the two above mentioned papers Grammatikos and Vermeulen (2012) base their study of the contagion from sovereigns to the banking sector on banks' equity returns. In order to detect contagion they use dummy variables to test whether there is a shift in some of the coefficients during crises. ${ }^{6}$ The authors find some evidence of shift contagion as the transmission of shocks is stronger during the 2007-2010 crisis. In particular, after the collapse of Lehman Brothers stock returns of financial firms have been more sensitive to changes in the Greek-German sovereign CDS spread. This suggests a contagion from sovereigns to banks. In a similar vein, using a crisis dummy, Bhanot et al. (2014) investigate the impact

\footnotetext{
${ }^{6}$ To determine the starting point of the financial crisis, Grammatikos and Vermeulen (2012) follow the Federal Reserve
} Bank of St. Louis' crisis timeline. 
of changes in Greek bond yield spreads on the daily abnormal financial sector returns in euro area crisis countries and in non-crisis countries. They also explore for evidence of news spillovers. Bhanot et al. (2014) find evidence of spillovers from the Greek bond yield to eurozone financial stock returns on days when there are ratings downgrades, suggesting the presence of information effects. In addition, they show that non-crisis countries are affected by ratings downgrades and bad news concerning Greece.

Overall, the results of the related literature point at some nonlinear transmission of shocks to banks during the period 2007-2011 and, more specifically, at some spillovers from the GIPS Sovereign debt crisis to the banking sector. We contribute to this literature in two ways. First, by using an expanded version of the Fama-French-Carhart multifactor model of banks' stock returns to control more comprehensively for the different channels of risk transmission to banks' stocks. Second, through a nonlinear modelling, allowing for an endogeneous definition of crisis periods and for a smooth transition between regimes. The data and the methodology used are presented in detail in the next section.

\section{Methodology and Data}

After introducing the empirical methodology, we present the data used in the regressions.

\subsection{The Methodology}

To assess whether and how the stock returns of European, Japanese, and U.S. banks have been impacted by the sovereign European debt crisis and by the previous episodes of financial turmoil experienced since 2007 we start from the four-factor model of Carhart (1997):

$$
R_{p, t}=\alpha+\beta_{M} R_{M, t}+\beta_{S M B} R_{S M B, t}+\beta_{H M L} R_{H M L, t}+\beta_{M O M} R_{M O M, t}+\varepsilon_{p, t}
$$

with $R_{p}$, the excess stock return - in local currency - of the banking sector of country $p$, for $p=B E, C H$, DE, ES, FN, FR, GB, GR, IE, IT, JP, NE, OE, PT, US.

Equation (1) nests the three-factor model of Fama and French (1993) as the special case where the momentum factor drops out $\left(\beta_{M O M}=0\right)$. Fama and French (1996) advocate that their three-factor model is the best benchmark model, as it accounts for most of the market anomalies left unexplained by the one factor Sharpe (1964) - Lintner (1965) CAPM. Indeed, according to Fama and French (1993) the empirical success of their model allows its interpretation as an equilibrium multifactor model of stock returns, consistent with the arbitrage pricing theory of Ross (1976). In this framework $R_{M, t} R_{S M B, t}$ and $R_{H M L, t}$ can be interpreted as three common sources of risk across stocks, namely the market risk of the CAPM and two other non-diversifiable risks: a small size risk, captured by $R_{S M B, t}$ and a distress risk, captured by $R_{H M L, t}$ However Fama and French (1996) acknowledge that their three-factor model does not account for the short run persistence of returns or momentum effect put into evidence by Jegadeesh and Titman (1993). Therefore, following Carhart (1997) we use the more general four-factor model (1) with the market factor proxied here by the return of a global market index and the three other factors (size, distress, and momentum) proxied by U.S. measures provided by Kenneth French. 
The sovereign European debt crisis of 2010-2011 undermined the recovery of European banks from the financial and banking crisis of 2007-2008: the downgrading of sovereign ratings fuelled the downgrading of banks, the sovereign debt holdings of banks depreciated as did the implicit sovereign guarantee to banks. The consequences of sovereign risks for the private sector of advanced countries have long been deemed negligible and, as such, have been neglected by the mainstream financial literature on stocks common risk factors. To allow for the specific additional risk entailed by the European sovereign debt crisis we add to equation (1), an European sovereign risk factor $R_{S O V, t}$ proxied by the change in the sovereign CDS of GIP countries. In order to take into account deviations from purchasing power parity, and considering that some misalignments may be amplified by the crisis episodes (and the fears of an eurozone implosion), exchange rate risk should be priced on the stock market (Dumas and Solnik, 1995) ${ }^{7}$, we therefore introduce the exchange rate return $R_{E R, t}$ (based on the USD/XXX exchange rate, where XXX is the country's currency code) as an additional control variable. Finally, to try to distinguish the exposure to the domestic sovereign from the exposure to the GIP sovereign debt crisis, we also include as an explanatory variable the lagged domestic sovereign risk, $R_{D O M, t-1}$, based on the domestic sovereign $C D S$. This expanded version of equation (1) yields:

$$
\begin{aligned}
R_{p, t}= & \alpha+\beta_{M} R_{M, t}+\beta_{S M B} R_{S M B, t-1}+\beta_{H M L} R_{H M L, t-1}+\beta_{M O M} R_{M O M, t-1}+\beta_{E R} E R_{t}+ \\
& \beta_{D O M} R_{D O M, t-1}+\beta_{S O V} R_{S O V, t}+\varepsilon_{p, t}
\end{aligned}
$$

where the U.S. size, distress, and momentum factors are lagged for all European countries and Japan to take into account non-synchronous trading with the United States.

As shown in section 2, the previous results of the literature suggest that some nonlinearities may have played a part in the transmission of risks to banks' stocks, during the recent episodes of crises. In order to formally allow for nonlinearities in the model and test for shift contagion (Forbes and Rigobon, 2001), we turn to a STR extension of equation (2) in which the coefficients may change during crisis episodes:

$$
\begin{aligned}
R_{p, t}= & \alpha^{L}+\beta_{M}^{L} R_{M, t}+\beta_{S M B}^{L} R_{S M B, t-1}+\beta_{H M L}^{L} R_{H M L, t-1}+\beta_{M O M}^{L} R_{M O M, t-1}+\beta_{E R}^{L} R_{E R, t}+ \\
& \beta_{D O M}^{L} R_{D O M, t-1}+\beta_{S O V}^{L} R_{S O V, t}+g\left(v_{t-\tau} ; \gamma, c\right)\left[\alpha^{N L}+\beta_{M}^{N L} R_{M, t}+\beta_{S M B}^{N L} R_{S M B, t-1}+\right. \\
& \left.\beta_{H M L}^{N L} R_{H M L, t-1}+\beta_{M O M}^{N L} R_{M O M, t-1+} \beta_{E R}^{N L} R_{E R, t}+\beta_{D O M}^{N L} R_{D O M, t-1}+R_{S O V, t}\right]+\varepsilon_{p, t}
\end{aligned}
$$

where the transition function $g\left(v_{t-\tau} ; \gamma, c\right)$ varies between 0 and 1 as the transition variable $v_{t-\tau}$ crosses the threshold $c$.

As we look for a transition variable $\left(v_{t-\tau}\right)$ that may represent crisis episodes in the euro area, we first opt for the VSTOXX (with 1 to $5 \operatorname{lag}(\mathrm{s})$ ), the implied volatility of the Eurostoxx50, a eurozone stock market index. ${ }^{8}$ In the high volatility regime, when the VSTOXX is above its threshold value $c$, we expect that some

\footnotetext{
${ }^{7}$ We thank an anonymous referee for this valuable insight.

${ }^{8}$ Like the VIX it rises in periods of global financial turmoil and high risk aversion and it can also be interpreted as an
} 
shifts may affect the coefficients and that they will be captured through the estimated coefficients in the second (nonlinear) part of equation (3).

As a robustness test and to further explore the nonlinearities that occur during crisis times, we also use two alternative transition variables: the iTraxx Financials Index (with 1 to $5 \operatorname{lag}(\mathrm{s})$ ) -which captures the credit risk of European banks and, more generally, the stress in the European banking system (Hui et al., 2013)and the lagged stock return $\left(R_{p, t \tau}\right)$.

The usual transition function $g$ may take a logistic or an exponential shape (Teräsvirta and Anderson, 1992). In the logistic STR with one threshold $c$ (LSTR), the $\mathrm{S}$ shaped transition function rises from 0 to 1 with the $\operatorname{VSTOXX}\left(v_{t-\tau}\right)$. It is defined as:

$$
g\left(v_{t-\tau} ; \gamma, c\right)=\frac{1}{1+e^{-\gamma\left(v_{t}-c\right)}} \text { with } \gamma>0
$$

Following Jansen and Teräsvirta (1996), the extension from one to two thresholds $c_{1}$ and $c_{2}$ gives rise to a $\mathrm{U}$ shaped transition function and to the exponential STR (ESTR) model. The transition function then becomes:

$$
g\left(v_{t-\tau} ; \gamma, c\right)=\frac{1}{1+e^{-\gamma\left(v_{t}-c_{1}\right)\left(v_{t}-c_{2}\right)}} \text { with } \gamma>0 \text { and } c_{2}>c_{1}
$$

In both transition functions a low slope parameter $\gamma$ results in a smooth transition. In the extreme case where $\gamma=0, g$ is constant and the STR reduces to a linear equation. In the opposite case where $\gamma$ takes very high values the transition function $\mathrm{g}$ jumps from 0 to 1 , according to the value of the threshold(s). In the LSTR model it jumps from 0 to 1 when $v_{t-\tau}$ rises above $c$. In the ESTAR model it jumps from 0 to 1 in two cases: when $v_{t-\tau}$ rises above $c_{2}$ and when it decreases below $c_{1}$.

In our framework we expect the transition function $g$ to increase only when the VSTOXX, or the iTraxx Financials index, or the lagged stock return rises above a relatively high threshold but not when it decreases below a more moderate threshold. Therefore a LSTR shape seems more appropriate than an ESTAR one. However, we follow the test sequence advocated by Teräsvirta $(1994,1998)$ to test for nonlinearities and choose the appropriate shape for $g$.

Testing for nonlinearities in equation (3) is nonstandard because of nuisance parameters (Hansen, 1996) that are not identified under the null hypothesis. We therefore resort to the auxiliary regression proposed by Luukkonen et al. (1988):

$$
R_{p, t}=\theta_{0}^{\prime} x_{t}+\theta_{1}^{\prime} x_{t} v_{t-\tau}+\theta_{2}^{\prime} x_{t} v_{t-\tau}^{2}+\theta_{3}^{\prime} x_{t} v_{t-\tau}^{3}+\xi_{t}
$$

where $x_{t}$ is a vector containing the constant and the explanatory variables of equation (2).

indicator of the global financial cycle (Rey, 2013). As we focus on European sovereign debt crisis, we use the VSTOXX insofar as, by construction, it is better suited than the VIX to capture the financial turmoil in Europe, during the Greek and eurozone crises. 
Testing for linearity then amounts to test:

$$
\mathrm{H}_{0}: \theta_{1}^{\prime}=\theta_{2}^{\prime}=\theta_{3}^{\prime}=0
$$

If linearity is rejected, following Teräsvirta $(1994,1998)$ we proceed to three exclusion tests:

$\mathrm{H}_{04}: \theta_{3}^{\prime}=0$

$\mathrm{H}_{03}: \theta_{2}^{\prime}=0 \mid \theta_{3}^{\prime}=0$

$\mathrm{H}_{02}: \theta_{1}^{\prime}=0 \mid \theta_{2}^{\prime}=\theta_{3}^{\prime}=0$

where the rejection of $\mathrm{H}_{03}$ supports the choice of an ESTR model, while the rejection of $\mathrm{H}_{04}$ and/or of $\mathrm{H}_{02}$ leads to an LSTR model.

\subsection{Data Sample}

We study the daily returns of the banking sector for eleven eurozone countries - Belgium (BE), Germany (DE), Spain (ES), Finland (FN), France (FR), Greece (GR), Ireland (IE), Italy (IT), the Netherlands (NE), Austria (OE), Portugal (PT) - and for the sake of comparison, we extend our analysis to four other countries: Switzerland (CH), the U.K. (GB), Japan (JP) and the U.S. (US). Switzerland and Japan may indeed play the role of safe havens during crises, at least for foreign exchange transactions (Ranaldo and Söderlind, 2010). The U.S. was at the epicenter of the global crisis, but appears to have benefited from US dollar funding shortages and flight-to-safety (McCauley and McGuire, 2009). The U.K. is characterized by a highly developed financial sector and close links both with Eurozone countries and with the U.S. The stock returns are the BANKSCC total return indices from Datastream, where CC is the country code. The series of banks' stock excess returns is then computed for each country as the difference between the daily stock returns of the banking sector and a proxy of the risk free rate. We take as proxy of the risk free rate for eurozone countries the German 3-month government interest rate adjusted for the number of trading days. For Switzerland, the U.K., Japan and the U.S. we take their domestic 3-month government interest rates, similarly adjusted for the number of trading days. ${ }^{9}$ The implied volatility in the eurozone STOXX stock market index, namely the VSTOXX index, and the iTraxx Financials index which tracks the total return on 5 -year CDS on the senior debt of 25 financial entities from the Markit iTraxx Europe index, are extracted from Datastream.

To test for the effect of the rise of sovereign risk in the eurozone on the stock returns of the banking sector of European countries (and Japan and the U.S.), we need a proxy $R_{S O V, t}$ of the sovereign debt risk in the euro area. We construct this proxy by using 5 -year euro area Sovereign senior CDS indices extracted from Datastream. The countries that experienced the highest increases of their Sovereign CDS indexes during the European crisis are Greece, Ireland and Portugal (GIP), which are also relatively small economies. We

\footnotetext{
9 As there is no perfect proxy of the risk free rate other options could have been retained, such as using the U.S. government interest rate as the risk free rate for all countries (using USD stock returns series) or the AAA euro benchmark yield for eurozone countries. However, as all these interest rates are at extremely low levels during the period under study they all yield proxies of daily risk free rates that are similar and extremely close to zero: the resulting excess returns are therefore almost exactly identical and essentially driven by the fluctuations in stock returns.
} 
therefore calculate an average sovereign CDS index for the GIP countries, using as weights the relative percentages of their governments consolidated gross debts extracted from Eurostat over 2007-2012. We then calculate $R_{S O V, t}$ simply as the first difference of the logged GIP sovereign CDS index. ${ }^{10}$ The GIP index is highly correlated with the larger GIIPS index (correlation of 0.99). However, we focus here on the narrower index, as we want to check whether the rise in the sovereign risk of small eurozone countries triggers contagion.

In order to be able to capture the specific effect of the rise of sovereign risks on the stock excess returns of the banking sector for the fifteen countries under study we have to control for other sources of common risks. As explained above, we consider the Fama-French-Carhart multifactor model that includes as explanatory variables: a global market factor, a size factor, a book-to market factor and a momentum variable. The global market factor $R_{M, t}$ is the excess global stock market return over the risk free interest rate. It is calculated as the difference between the daily total return of the MSCI, IMI Equity index extracted from Macrobond and the 3-month U.S. government yield benchmark, adjusted for the number of trading days. The size factor $R_{S M B, t}$ the spread between the returns on small and big stocks, and the book-to-market factor $R_{H M L, t}$ the spread between the returns of high book-to-market stocks (value stocks) and low ones (growth stocks), are the U.S. Fama and French research factors, downloaded from the website of Kenneth French, where their exact description can be found. ${ }^{11}$ The momentum factor $R_{M O M, t}$ the spread between the returns of past winners (U.S. stocks with the highest prior returns) and past losers (U.S. stocks with the lowest prior returns), comes from the same source. ${ }^{12}$ Any positive (negative) correlation of European banks stock returns with these three factors may therefore also represent a positive (negative) correlation with the U.S. stock market. To deal with the issue of non-synchronous trading between the U.S. and the other countries we use in our regressions (except for the U.S.) the lagged size, book-to-market and momentum U.S. factors instead of the contemporaneous ones (Bae et al., 2003; Beine et al., 2010). All these explanatory variables are converted to the local currency of the banks' country. The exchange rate return $R_{E R, t}$ is calculated as the first difference of the logged USD/EUR exchange rate for both eurozone countries and the U.S., and as the first difference of the logged USD/XXX exchange rate for the other countries, where $\mathrm{XXX}$ is the code for the domestic currency. Finally, as mentioned in section 3.1, we also include as a control variable the lagged domestic sovereign CDS spread $R_{D O M, t-1}$.

Our data span the period going from December, 142007 to March, 8 2013. The eurozone sovereign CDS spreads were low and stable before December 2007: they began to increase a bit in the aftermath of Lehman Brothers failure and surged in the wake of the Greek crisis. They peaked in February 2012 after the ratification of the second bailout programme of Greece. Then the sovereign CDS spreads of eurozone countries declined rapidly and returned to their previous level, with the exception of Greece. As the Greek

\footnotetext{
10 We could have used the GIIPS sovereign CDS index, which yields similar results. However the GIP and GIIPS indexes are very close and we prefer to use the narrower one as we want to focus on contagion (from GIP to other countries).

${ }^{11}$ See http://mba.tuck.dartmouth.edu/pages/faculty/ken.french/Data Library/f-f factors.html.

${ }^{12}$ See http://mba.tuck.dartmouth.edu/pages/faculty/ken.french/Data_Library/det mom factor daily.html.
} 
debt restructuration was forced on some lenders, Greece was considered to be in default. Its CDSs were activated in February 2012 and Greece became entirely depend on the Troika to renew its debt and ensure the functioning of its banking system. Our estimation period spanning 14/12/2007- 8/3/2013 allows us to capture the impact of the rise in the GIP sovereign risk on the banking sectors of the 15 countries under study and the repercussions of the Greek default in February 2012.

Table A1 displays the summary statistics for our data. To avoid stale quotes (when a market is closed) we filter out for each country all the observations for which the stock returns of the banking sector are strictly equal to zero. Therefore the final number of retained observations varies from 1270 for the stock returns of the Greek banking sector to 1316 for the U.S. one. In addition, heteroscedasticity is corrected with the consistent standard errors procedure proposed by White.

\section{Results}

As a first step, following the recommendation of Terasvirta (1994) and to provide a benchmark, we estimate the linear version of the model (Eq. 2) for each of the fifteen countries under study. We then proceed to the estimation of the LSTR model of Equation (3).

\subsection{Results for the linear regressions of banks' returns}

The estimations of the linear equation of returns (Eq. 2), reported in Table 2.1 confirm that our extended version of the Carhart four factors model is appropriate to capture the main common factors of risks of banks' stocks. To account for the conditional heteroskedasticity detected by the LM-ARCH test of Engle (1982) we jointly estimate the extended version of the Fama-French-Carhart model (Eq. 2) for the returns and a GARCH(1,1) model for the conditional volatility. Besides, we account for the slight autocorrelation that may characterize stock returns by adding up to five lags of the dependent variable as explanatory variables in the return equation ${ }^{13}$.

The GIP sovereign risk captured by $R_{S O V}$ significantly impacts the banking sector in all the fifteen countries under study, except Japan. There is however a major difference between Europe and the U.S. Whereas European banks stocks are adversely hit by the rise in the sovereign CDS of the GIP - with estimates for $\beta_{\text {SOV }}$ ranging from -0.22 for Greece to -0.02 for Switzerland - U.S. banks' equity returns seem to slightly benefit from the eurozone crisis (with $\beta_{S O V}=0.04$ ), through what might be a kind of flight-to-quality effect (McCauley and McGuire, 2009). The U.S. banks have the privilege of delivering international liquidity in the form of USD, which were much sought during and after the global crisis (McCauley and McGuire, 2009).

\footnotetext{
13 As these lags do not in general appear to be significant and are not the core of our model, we do not report their estimated coefficients. To add or remove these lags does not change the coefficients of the other explanatory variables of equation (2). However we prefer to keep them in the regression as a weak autocorrelation over the past five days (week) may be statistically difficult to detect.
} 
Table 2.1: Results of the linear estimations of the multifactor model of banks returns

\begin{tabular}{|c|c|c|c|c|c|c|c|c|c|c|c|c|c|c|c|}
\hline & $B E$ & $D E$ & $E S$ & $F N$ & FR & GR & $I E$ & $I T$ & $N E$ & $O E$ & $P T$ & $\mathrm{CH}$ & $G B$ & $J P$ & $U S$ \\
\hline$\alpha$ & $\begin{array}{l}-0.07 \\
(0.35)\end{array}$ & $\begin{array}{l}-0.05 \\
(0.25)\end{array}$ & $\begin{array}{c}0.01 \\
(0.80)\end{array}$ & $\begin{array}{c}0.07 \\
(0.18)\end{array}$ & $\begin{array}{l}-0.01 \\
(0.89)\end{array}$ & $\begin{array}{l}-0.16 \\
(0.13)\end{array}$ & $\begin{array}{l}-0.17 \\
(0.21)\end{array}$ & $\begin{array}{l}-0.05 \\
(0.35)\end{array}$ & $\begin{array}{c}-0.19 \\
(<0.01)\end{array}$ & $\begin{array}{c}0.03 \\
(0.50)\end{array}$ & $\begin{array}{c}-0.09 \\
(0.13)\end{array}$ & $\begin{array}{c}0.02 \\
(0.83)\end{array}$ & $\begin{array}{c}-0.01 \\
(0.91)\end{array}$ & $\begin{array}{c}0.03 \\
(0.39)\end{array}$ & $\begin{array}{c}-0.09 \\
(0.02)\end{array}$ \\
\hline$\beta_{R M}$ & $\begin{array}{c}1.51 \\
(<0.01)\end{array}$ & $\begin{array}{c}1.51 \\
(<0.01)\end{array}$ & $\begin{array}{c}1.17 \\
(<0.01)\end{array}$ & $\begin{array}{c}1.18 \\
(<0.01)\end{array}$ & $\begin{array}{c}1.40 \\
(<0.01)\end{array}$ & $\begin{array}{c}0.79 \\
(<0.01)\end{array}$ & $\begin{array}{c}1.57 \\
(<0.01)\end{array}$ & $\begin{array}{c}1.19 \\
(<0.01)\end{array}$ & $\begin{array}{c}0.43 \\
(<0.01)\end{array}$ & $\begin{array}{c}1.34 \\
(<0.01)\end{array}$ & $\begin{array}{c}0.68 \\
(<0.01)\end{array}$ & $\begin{array}{c}1.32 \\
(<0.01)\end{array}$ & $\begin{array}{c}1.41 \\
(<0.01)\end{array}$ & $\begin{array}{c}0.42 \\
(<0.01)\end{array}$ & $\begin{array}{r}1.17 \\
(<0.01) \\
\end{array}$ \\
\hline$\beta_{S M B}$ & $\begin{array}{c}0.02 \\
(0.91)\end{array}$ & $\begin{array}{l}-0.09 \\
(0.34)\end{array}$ & $\begin{array}{l}-0.11 \\
(0.10)\end{array}$ & $\begin{array}{c}0.03 \\
(0.71)\end{array}$ & $\begin{array}{l}-0.12 \\
(0.20)\end{array}$ & $\begin{array}{c}-0.02 \\
(0.88)\end{array}$ & $\begin{array}{c}0.22 \\
(0.46)\end{array}$ & $\begin{array}{l}-0.04 \\
(0.64)\end{array}$ & $\begin{array}{c}0.11 \\
(0.10)\end{array}$ & $\begin{array}{l}-0.03 \\
(0.75) \\
\end{array}$ & $\begin{array}{c}0.02 \\
(0.81)\end{array}$ & $\begin{array}{c}-0.12 \\
(0.10)\end{array}$ & $\begin{array}{c}-0.14 \\
(0.17)\end{array}$ & $\begin{array}{c}0.08 \\
(0.11)\end{array}$ & $\begin{array}{c}0.16 \\
(0.27) \\
\end{array}$ \\
\hline$\beta_{H M L L}$ & $\begin{array}{c}0.44 \\
(<0.01)\end{array}$ & $\begin{array}{c}0.18 \\
(0.09) \\
\end{array}$ & $\begin{array}{c}0.26 \\
(<0.01) \\
\end{array}$ & $\begin{array}{c}0.26 \\
(<0.01)\end{array}$ & $\begin{array}{c}0.38 \\
(<0.01)\end{array}$ & $\begin{array}{c}0.28 \\
(0.02) \\
\end{array}$ & $\begin{array}{c}0.24 \\
(0.28) \\
\end{array}$ & $\begin{array}{c}0.21 \\
(0.01) \\
\end{array}$ & $\begin{array}{c}0.03 \\
(0.61) \\
\end{array}$ & $\begin{array}{c}0.22 \\
(<0.01)\end{array}$ & $\begin{array}{c}0.27 \\
(<0.01)\end{array}$ & $\begin{array}{c}0.41 \\
(<0.01)\end{array}$ & $\begin{array}{c}0.43 \\
(<0.01)\end{array}$ & $\begin{array}{c}0.25 \\
(<0.01)\end{array}$ & $\begin{array}{r}2.21 \\
(<0.01) \\
\end{array}$ \\
\hline$\beta_{M O M}$ & $\begin{array}{c}-0.36 \\
(<0.01) \\
\end{array}$ & $\begin{array}{l}-0.08 \\
(0.07) \\
\end{array}$ & $\begin{array}{c}-0.12 \\
(<0.01)\end{array}$ & $\begin{array}{c}-0.21 \\
(<0.01) \\
\end{array}$ & $\begin{array}{c}-0.25 \\
(<0.01)\end{array}$ & $\begin{array}{l}-0.14 \\
(0.07) \\
\end{array}$ & $\begin{array}{l}-0.36 \\
(0.03) \\
\end{array}$ & $\begin{array}{c}-0.12 \\
(<0.01) \\
\end{array}$ & $\begin{array}{l}-0.04 \\
(0.27) \\
\end{array}$ & $\begin{array}{c}-0.19 \\
(<0.01) \\
\end{array}$ & $\begin{array}{l}-0.10 \\
(0.03) \\
\end{array}$ & $\begin{array}{c}-0.19 \\
(<0.01) \\
\end{array}$ & $\begin{array}{c}-0.25 \\
(<0.01) \\
\end{array}$ & $\begin{array}{c}-0.31 \\
(<0.01)\end{array}$ & $\begin{array}{r}-0.51 \\
(<0.01) \\
\end{array}$ \\
\hline$\beta_{E R}$ & $\begin{array}{c}-1.96 \\
(<0.01)\end{array}$ & $\begin{array}{c}-1.81 \\
(<0.01)\end{array}$ & $\begin{array}{c}-1.70 \\
(<0.01)\end{array}$ & $\begin{array}{c}-1.31 \\
(<0.01)\end{array}$ & $\begin{array}{c}-1.95 \\
(<0.01)\end{array}$ & $\begin{array}{c}-1.36 \\
(<0.01)\end{array}$ & $\begin{array}{c}-1.80 \\
(<0.01)\end{array}$ & $\begin{array}{c}-1.89 \\
(<0.01)\end{array}$ & $\begin{array}{c}-0.29 \\
(<0.01)\end{array}$ & $\begin{array}{c}-1.72 \\
(<0.01)\end{array}$ & $\begin{array}{c}-1.21 \\
(<0.01)\end{array}$ & $\begin{array}{c}-1.32 \\
(<0.01) \\
\end{array}$ & $\begin{array}{c}-1.49 \\
(<0.01)\end{array}$ & $\begin{array}{c}-0.06 \\
(0.24)\end{array}$ & $\begin{array}{r}0.28 \\
(<0.01) \\
\end{array}$ \\
\hline$\beta_{D O M}$ & $\begin{array}{c}0.01 \\
(0.65)\end{array}$ & $\begin{array}{c}0.01 \\
(0.23)\end{array}$ & $\begin{array}{l}-0.02 \\
(0.12)\end{array}$ & $\begin{array}{l}-0.01 \\
(0.87)\end{array}$ & $\begin{array}{c}0.01 \\
(0.52)\end{array}$ & $\begin{array}{l}-0.01 \\
(0.75)\end{array}$ & $\begin{array}{l}-0.01 \\
(0.76)\end{array}$ & $\begin{array}{l}-0.02 \\
(0.19)\end{array}$ & $\begin{array}{c}0.01 \\
(0.52)\end{array}$ & $\begin{array}{c}0.01 \\
(0.50)\end{array}$ & $\begin{array}{l}-0.01 \\
(0.78)\end{array}$ & $\begin{array}{c}-0.11 \\
(0.33)\end{array}$ & $\begin{array}{c}0.01 \\
(0.50)\end{array}$ & $\begin{array}{c}0.01 \\
(0.13)\end{array}$ & $\begin{array}{c}0.01 \\
(0.12)\end{array}$ \\
\hline$\beta_{\text {SOV }}$ & $\begin{array}{c}-0.10 \\
(<0.01)\end{array}$ & $\begin{array}{c}-0.04 \\
(<0.01)\end{array}$ & $\begin{array}{c}-0.08 \\
(<0.01)\end{array}$ & $\begin{array}{c}-0.07 \\
(<0.01)\end{array}$ & $\begin{array}{c}-0.08 \\
(<0.01)\end{array}$ & $\begin{array}{c}-0.22 \\
(<0.01)\end{array}$ & $\begin{array}{l}-0.08 \\
(0.05)\end{array}$ & $\begin{array}{c}-0.07 \\
(<0.01)\end{array}$ & $\begin{array}{c}-0.03 \\
(0.03)\end{array}$ & $\begin{array}{c}-0.07 \\
(<0.01)\end{array}$ & $\begin{array}{c}-0.07 \\
(<0.01)\end{array}$ & $\begin{array}{c}-0.02 \\
(0.02)\end{array}$ & $\begin{array}{c}-0.03 \\
(0.01)\end{array}$ & $\begin{array}{c}0.01 \\
(0.87)\end{array}$ & $\begin{array}{r}0.04 \\
(<0.01) \\
\end{array}$ \\
\hline$c$ & $\begin{array}{c}0.27 \\
(0.13) \\
\end{array}$ & $\begin{array}{c}0.02 \\
(0.01) \\
\end{array}$ & $\begin{array}{c}0.07 \\
(<0.01)\end{array}$ & $\begin{array}{c}0.04 \\
(0.01) \\
\end{array}$ & $\begin{array}{c}0.04 \\
(0.02) \\
\end{array}$ & $\begin{array}{c}0.16 \\
(0.03) \\
\end{array}$ & $\begin{array}{c}0.99 \\
(<0.01)\end{array}$ & $\begin{array}{c}0.04 \\
(0.01) \\
\end{array}$ & $\begin{array}{c}0.38 \\
(<0.01)\end{array}$ & $\begin{array}{c}0.04 \\
(0.03) \\
\end{array}$ & $\begin{array}{c}0.07 \\
(0.04) \\
\end{array}$ & $\begin{array}{c}0.03 \\
(0.01) \\
\end{array}$ & $\begin{array}{c}0.02 \\
(0.01) \\
\end{array}$ & $\begin{array}{c}0.04 \\
(0.02) \\
\end{array}$ & $\begin{array}{r}0.1 \\
(0.04) \\
\end{array}$ \\
\hline$a$ & $\begin{array}{c}0.17 \\
(0.02) \\
\end{array}$ & $\begin{array}{c}0.05 \\
(<0.01)\end{array}$ & $\begin{array}{c}0.08 \\
(<0.01)\end{array}$ & $\begin{array}{c}0.08 \\
(<0.01)\end{array}$ & $\begin{array}{c}0.09 \\
(<0.01)\end{array}$ & $\begin{array}{c}0.08 \\
(<0.01)\end{array}$ & $\begin{array}{c}0.21 \\
(<0.01)\end{array}$ & $\begin{array}{c}0.07 \\
(<0.01)\end{array}$ & $\begin{array}{c}0.34 \\
(<0.01)\end{array}$ & $\begin{array}{c}0.06 \\
(<0.01)\end{array}$ & $\begin{array}{c}0.07 \\
(<0.01)\end{array}$ & $\begin{array}{c}0.08 \\
(<0.01)\end{array}$ & $\begin{array}{c}0.06 \\
(<0.01)\end{array}$ & $\begin{array}{c}0.08 \\
(<0.01)\end{array}$ & $\begin{array}{c}0.07 \\
(<0.01) \\
\end{array}$ \\
\hline$b$ & $\begin{array}{c}0.80 \\
(<0.01)\end{array}$ & $\begin{array}{c}0.94 \\
(<0.01)\end{array}$ & $\begin{array}{c}0.90 \\
(<0.01)\end{array}$ & $\begin{array}{c}0.91 \\
(<0.01)\end{array}$ & $\begin{array}{c}0.90 \\
(<0.01)\end{array}$ & $\begin{array}{c}0.90 \\
(<0.01)\end{array}$ & $\begin{array}{c}0.77 \\
(<0.01)\end{array}$ & $\begin{array}{c}0.92 \\
(<0.01)\end{array}$ & $\begin{array}{c}0.62 \\
(<0.01)\end{array}$ & $\begin{array}{c}0.93 \\
(<0.01)\end{array}$ & $\begin{array}{c}0.91 \\
(<0.01)\end{array}$ & $\begin{array}{c}0.90 \\
(<0.01)\end{array}$ & $\begin{array}{c}0.93 \\
(<0.01)\end{array}$ & $\begin{array}{c}0.90 \\
(<0.01)\end{array}$ & $\begin{array}{r}0.92 \\
(<0.01) \\
\end{array}$ \\
\hline ARCH & $\begin{array}{c}48.62 \\
(<0.01)\end{array}$ & $\begin{array}{c}86.71 \\
(<0.01)\end{array}$ & $\begin{array}{c}46.04 \\
(<0.01)\end{array}$ & $\begin{array}{c}147.7 \\
(<0.01)\end{array}$ & $\begin{array}{c}88.48 \\
(<0.01)\end{array}$ & $\begin{array}{c}94.01 \\
(<0.01)\end{array}$ & $\begin{array}{c}201.7 \\
(<0.01)\end{array}$ & $\begin{array}{c}44.09 \\
(<0.01)\end{array}$ & $\begin{array}{c}250.9 \\
(<0.01)\end{array}$ & $\begin{array}{c}157.9 \\
(<0.01)\end{array}$ & $\begin{array}{c}91.31 \\
(<0.01)\end{array}$ & $\begin{array}{c}128.6 \\
(<0.01)\end{array}$ & $\begin{array}{c}185.0 \\
(<0.01)\end{array}$ & $\begin{array}{c}161.1 \\
(<0.01)\end{array}$ & $\begin{array}{r}213.8 \\
(<0.01) \\
\end{array}$ \\
\hline AR & $\begin{array}{c}8.85 \\
(0.18) \\
\end{array}$ & $\begin{array}{c}9.22 \\
(0.16) \\
\end{array}$ & $\begin{array}{c}5.69 \\
(0.46) \\
\end{array}$ & $\begin{array}{c}4.73 \\
(0.58) \\
\end{array}$ & $\begin{array}{c}2.85 \\
(0.83) \\
\end{array}$ & $\begin{array}{c}3.50 \\
(0.74)\end{array}$ & $\begin{array}{c}5.71 \\
(0.46) \\
\end{array}$ & $\begin{array}{c}5.69 \\
(0.46) \\
\end{array}$ & $\begin{array}{c}7.75 \\
(0.26) \\
\end{array}$ & $\begin{array}{c}7.28 \\
(0.30) \\
\end{array}$ & $\begin{array}{c}4.17 \\
(0.65) \\
\end{array}$ & $\begin{array}{c}10.55 \\
(0.11)\end{array}$ & $\begin{array}{c}8.41 \\
(0.21) \\
\end{array}$ & $\begin{array}{c}5.18 \\
(0.52) \\
\end{array}$ & $\begin{array}{r}5.53 \\
(0.48) \\
\end{array}$ \\
\hline
\end{tabular}

Note: These tables report the results from the estimation of Eq. (2) over 14/12/2007-08/03/2013:

$$
R_{p, t}=\alpha+\beta_{M} R_{M, t}+\beta_{S M B} R_{S M B, t-1}+\beta_{H M L} R_{H M L, t-1}+\beta_{M O M} R_{M O M, t-1}+\beta_{E R} E R_{t}+\beta_{D O M} R_{D O M, t-1}+\beta_{S O V} R_{S O V, t}+\varepsilon_{p, t}
$$

together with the GARCH(1,1) model for the conditional variance $\left(h_{t}\right): h_{t}=c+a \varepsilon_{t-1}^{2}+b h_{t-1}$

Where $\beta_{M}$ and $\beta_{S M B}, \beta_{H M L}, \beta_{M O M}$ denote the coefficients of, respectively, the global market factor and the three U.S. Fama-French and Carhart factors: small minus big firms returns, returns of high book to market firms minus low ones and a momentum factor. These last three factors are lagged for all European countries and Japan to take into account nonsynchronous trading with the United States. $\beta_{E R}$ is the coefficient on the change in the logged USD/XXX exchange rate (for XXX equal to EUR for the Eurozone and the U.S. and to either CHF or GBP or JPY the other countries). $\beta_{D O M}$ is the coefficient of the domestic sovereign rating's lagged change. $\beta_{S O V}$ is the coefficient of the average change in GIP sovereign CDS spreads. Marginal significance levels are given in parentheses. The line ARCH reports the results of the LM-ARCH test of Engle (1982) of order 6 for non standardized residuals. The line AR reports the results for the Ljung-Box test for autocorrelation of order 6 for standardized residuals. Country codes are given at the beginning of Section 3.2 . 
This finding may also be related to the relatively shorter delay with which U.S. banks have, in the aftermath of Lehman Brothers' failure, cleaned up their balance sheets of distressed assets, which has given them an advantage over their European counterparts. Besides, contrary to the eurozone, the U.S. benefit from a fiscal integration and where never threatened by a collapse of their federal structure during the period 2007-2013. Lastly, U.S. banks were much less exposed than European banks to the sovereign debt of GIP. For all these reasons international investors in the financial sector or firms seeking international liquidity would rather turn to U.S. banks rather than to European ones, during the eurozone sovereign debt crisis.

The specification of this model of banks returns appears globally satisfactory. The Ljung-Box test rejects consistently the hypothesis of the autocorrelation of errors and the GARCH specification of heteroskedasticity is upported both by the ARCH test and the significance of the estimates of $a$ and $b$.

The equity returns of banks comove strongly with the global market factor, with estimates for the global market $\beta$ above or equal to one, except for Greece, the Netherlands, Portugal and Japan. This result is consistent with the conclusions of Poirson and Schmittman (2013), who remark that over the period20072011 banks' stocks are characterized by high global market $\beta$ s. The $\beta$ of the momentum factor is consistently negative and significant (except for the Netherlands): unsurprisingly, considering the period under study, banks stock returns comove with the returns of past losers rather than with past winners.

On the opposite, the distress factor $\left(R_{H M L}\right)$ appears to be positively correlated with banks stock returns. The results for the size factor are more ambiguous: when significant at the $10 \%$ level the estimate of $\beta_{S M B}$ can be positive - as is the case for the Netherlands - or negative (Spain and Switzerland). Normally we would expect the returns of banks stocks to be negatively correlated with the small size factor, as banks are generally large firms. However small firms and banks have both be badly hit by the global crisis and the European crisis. As expected, European banks stock returns decrease when the dollar appreciates $\left(\boldsymbol{\beta}_{E R}<0\right)$, whereas U.S. banks stock returns increase. The Japanese banking sector's stock return appears unaffected by the exchange rate. The lagged domestic sovereign factor $\left(R_{D O M}\right)$ is never significant: we therefore drop this variable in the following non linear regressions.

\subsection{Detection and shape of nonlinearities}

The results of the preliminary nonlinearity tests and of the choice between LSTR and ESTR models are reported in Table A2 in Appendix. Linearity is consistently rejected and the final selected model is always an LSTR. ${ }^{14}$ We therefore proceed with the estimations of LSTR models. The misspecifications tests reported in table A3 in appendix confirm that the estimated models are satisfactory. The final results of the Smooth Transition Regressions based on the multifactor stock return model of equation (3) are displayed in Tables 3.1 to 3.4 and commented in detail below and in the following subsections.

The nonlinear LSTR model with the VSTOXX as a transition variable $\left(v_{\mathrm{t}-\tau}\right)$ is supported by the results of

\footnotetext{
${ }^{14}$ Except in five cases out of forty five, where the selected model is an ESTAR. However in these five cases most of the observations lie on one side of the estimated threshold value and the ESTAR model works as a substitute to a LSTAR model (Teräsvirta, 1994). We therefore finally select and estimate LSTR models in these cases..
} 
the smooth transition regressions (Tables 3.1 and 3.4). All the countries under study experience significant shifts ${ }^{15}$ in the factors coefficients when the risk aversion increases on the European stock market: some shift contagion seems therefore to have been at work during the last crises. In particular there is in the majority of cases a shift in $\beta_{\text {SOV }}$ when the VSTOXX rises above its threshold. ${ }^{16}$ The LSTR model allows to fit both smooth (Japan, Portugal, the U.S.) and rough transitions. The estimates for the threshold $c$ for the VSTOXX are mostly comprised between 40 and 50 .

The nonlinear LSTR model with the iTraxx Financials index as a transition variable $\left(v_{t-\tau}\right)$ is also supported by the results of the smooth transition regressions (Tables 3.2 and 3.4). All the countries under study experience significant shifts ${ }^{17}$ in the factors coefficients when the European Stock market volatility increases: some shift contagion appears to have been at work during the last crises, though its channel appears to be more often the exchange rate factor $\left(R_{E R}\right)$ than the GIP Sovereign CDS ( $\left.R_{S O V}\right)$. The LSTR model allows to fit both smooth (Belgium, Germany, Finland, France, Greece, Italy, Portugal, the U.K.) and rough transitions. The estimates for the threshold $c$ for the iTraxx Financials index are mostly above 150, with a maximum at 193.87 (Germany).

When the lagged return of the banking sector $\left(R_{p, t-\tau}\right)$ is used as the transition variable $\left(v_{t-\tau}\right)$ significant changes in the parameters (Tables 3.3 and 3.4) are observed when the regime changes - moving here from relatively poor past returns to better ones as $v_{t-\tau}$ increases above $c$-supporting the nonlinear LSTR specification. The LSTR model allows here again to fit both smooth (Belgium, Finland, Austria, Switzerland, Japan) and rough transitions. The estimates for the threshold $c$ for the lagged return of the banking sector $\left(R_{p, t-\tau}\right)$ are mostly negative and below $-2 \%$ with the exceptions of Belgium, Austria and the U.S.

\subsection{Detailed results for the Smooth Transition Regressions of banks' returns}

Table 3.1 displays the results of the nonlinear regressions for eurozone countries when the transition variable is the VSTOXX. As regards the impact of GIP sovereign risk, the results displayed in Table 3.1 confirm that in all the eurozone countries under study the banks' stock returns have at some point been negatively impacted by the rise in the sovereign CDS of Greece, Ireland and Portugal (GIP). Indeed, either

$\beta_{S O V}^{L}$ and/or $\beta_{S O V}^{N L}$ are negative for all eurozone countries and their sum is always below zero: when the VSTOXX surges above a threshold ( $c$ ) estimated between 32 (for Spain) and 62 (for Austria) eurozone banks stock returns drop in response to a rise in the sovereign risk of the three countries most adversely hit by the European sovereign debt crisis. This finding is broadly consistent with the results of Chan-Lau et al. (2015) and Grammatikos and Vermeulen (2012) concerning the transmission of sovereign risks to banks during the period 2008-2011. For Germany and Finland this negative impact is slight $\left(\beta_{\text {SOV }}^{L}=-0.03\right.$ or -0.04 and $\beta_{S O V}^{N L}=0$ cannot be rejected), but nonetheless significant.

\footnotetext{
15 At the $10 \%$ significance level for Japan (5\% for other countries).

${ }^{16}$ At the $10 \%$ significance level (5\% for eurozone countries).

${ }^{17}$ At the $10 \%$ significance level for Japan (5\% for other countries).
} 
Table 3.1: Results of the nonlinear estimations of the multifactor model of bank returns for eurozone countries with the lagged VSTOXX as the transition variable

\begin{tabular}{|c|c|c|c|c|c|c|c|c|c|c|c|}
\hline & $B E$ & $D E$ & $E S$ & $F N$ & $F R$ & $G R$ & $I E$ & $I T$ & $N E$ & $O E$ & $P T$ \\
\hline \multicolumn{12}{|c|}{ Linear Parameters } \\
\hline$\alpha^{L}$ & $\begin{array}{l}-0.02 \\
(0.71)\end{array}$ & $\begin{array}{l}-0.03 \\
(0.46)\end{array}$ & $\begin{array}{l}-0.06 \\
(0.17)\end{array}$ & $\begin{array}{c}0.03 \\
(0.59)\end{array}$ & $\begin{array}{l}-0.01 \\
(0.84)\end{array}$ & $\begin{array}{l}-0.09 \\
(0.42)\end{array}$ & $\begin{array}{l}-0.21 \\
(0.11)\end{array}$ & $\begin{array}{c}-0.11 \\
(0.05)\end{array}$ & $\begin{array}{c}-0.20 \\
(<0.01)\end{array}$ & $\begin{array}{l}-0.01 \\
(0.86)\end{array}$ & $\begin{array}{l}-0.10 \\
(0.11)\end{array}$ \\
\hline$\beta_{M}^{L}$ & $\begin{array}{c}1.89 \\
(<0.01)\end{array}$ & $\begin{array}{c}1.65 \\
(<0.01)\end{array}$ & $\begin{array}{c}1.38 \\
(<0.01)\end{array}$ & $\begin{array}{c}1.35 \\
(<0.01)\end{array}$ & $\begin{array}{c}1.77 \\
(<0.01)\end{array}$ & $\begin{array}{c}1.00 \\
(<0.01)\end{array}$ & $\begin{array}{c}2.10 \\
(<0.01)\end{array}$ & $\begin{array}{c}1.39 \\
(<0.01)\end{array}$ & $\begin{array}{c}0.85 \\
(<0.01)\end{array}$ & $\begin{array}{c}1.35 \\
(<0.01)\end{array}$ & $\begin{array}{c}0.96 \\
(<0.01)\end{array}$ \\
\hline$\beta_{S M B}^{L}$ & $\begin{array}{c}-0.01 \\
(0.98) \\
\end{array}$ & $\begin{array}{l}-0.08 \\
(0.26)\end{array}$ & $\begin{array}{l}-0.08 \\
(0.33)\end{array}$ & $\begin{array}{l}-0.03 \\
(0.75)\end{array}$ & $\begin{array}{l}-0.15 \\
(0.10) \\
\end{array}$ & $\begin{array}{l}-0.17 \\
(0.28)\end{array}$ & $\begin{array}{c}0.66 \\
(0.02) \\
\end{array}$ & $\begin{array}{l}-0.09 \\
(0.30)\end{array}$ & $\begin{array}{c}0.15 \\
(0.32) \\
\end{array}$ & $\begin{array}{c}0.06 \\
(0.54)\end{array}$ & $\begin{array}{l}-0.07 \\
(0.48)\end{array}$ \\
\hline$\beta_{H L M}^{L}$ & $\begin{array}{c}0.49 \\
(<0.01)\end{array}$ & $\begin{array}{c}0.23 \\
(<0.01)\end{array}$ & $\begin{array}{c}0.21 \\
(<0.01)\end{array}$ & $\begin{array}{c}0.44 \\
(<0.01)\end{array}$ & $\begin{array}{c}0.40 \\
(<0.01)\end{array}$ & $\begin{array}{c}0.44 \\
(<0.01)\end{array}$ & $\begin{array}{c}0.31 \\
(0.20)\end{array}$ & $\begin{array}{c}0.27 \\
(<0.01)\end{array}$ & $\begin{array}{c}0.32 \\
(0.03)\end{array}$ & $\begin{array}{c}0.22 \\
(0.01)\end{array}$ & $\begin{array}{c}0.32 \\
(<0.01)\end{array}$ \\
\hline$\beta_{M O M}^{L}$ & $\begin{array}{c}-0.28 \\
(<0.01)\end{array}$ & $\begin{array}{l}-0.06 \\
(0.20)\end{array}$ & $\begin{array}{l}-0.10 \\
(0.06)\end{array}$ & $\begin{array}{c}-0.20 \\
(<0.01)\end{array}$ & $\begin{array}{c}-0.30 \\
(<0.01)\end{array}$ & $\begin{array}{l}-0.16 \\
(0.08)\end{array}$ & $\begin{array}{c}-0.54 \\
(<0.01)\end{array}$ & $\begin{array}{l}-0.13 \\
(0.01)\end{array}$ & $\begin{array}{l}-0.13 \\
(0.06)\end{array}$ & $\begin{array}{c}-0.21 \\
(<0.01)\end{array}$ & $\begin{array}{l}-0.11 \\
(0.08)\end{array}$ \\
\hline$\beta_{E R}^{L}$ & $\begin{array}{c}-2.32 \\
(<0.01)\end{array}$ & $\begin{array}{c}-1.87 \\
(<0.01)\end{array}$ & $\begin{array}{c}-1.94 \\
(<0.01)\end{array}$ & $\begin{array}{c}-1.55 \\
(<0.01)\end{array}$ & $\begin{array}{c}-2.29 \\
(<0.01)\end{array}$ & $\begin{array}{c}-1.67 \\
(<0.01)\end{array}$ & $\begin{array}{c}-2.15 \\
(<0.01)\end{array}$ & $\begin{array}{c}-2.23 \\
(<0.01)\end{array}$ & $\begin{array}{c}-0.40 \\
(<0.01)\end{array}$ & $\begin{array}{l}-1.86 \\
(<0.01)\end{array}$ & $\begin{array}{c}-1.53 \\
(<0.01)\end{array}$ \\
\hline$\beta_{S O V}^{L}$ & $\begin{array}{c}-0.08 \\
(<0.01) \\
\end{array}$ & $\begin{array}{l}-0.03 \\
(0.02) \\
\end{array}$ & $\begin{array}{c}-0.06 \\
(<0.01) \\
\end{array}$ & $\begin{array}{c}-0.04 \\
(<0.01) \\
\end{array}$ & $\begin{array}{l}-0.06 \\
(0.01) \\
\end{array}$ & $\begin{array}{c}-0.21 \\
(<0.01)\end{array}$ & $\begin{array}{l}-0.01 \\
(0.84) \\
\end{array}$ & $\begin{array}{c}-0.04 \\
(<0.01)\end{array}$ & $\begin{array}{l}-0.01 \\
(0.90) \\
\end{array}$ & $\begin{array}{c}-0.06 \\
(<0.01) \\
\end{array}$ & $\begin{array}{c}-0.05 \\
(<0.01) \\
\end{array}$ \\
\hline \multicolumn{12}{|c|}{ Nonlinear Parameters } \\
\hline$\alpha^{N L}$ & $\begin{array}{c}-0.52 \\
(0.30) \\
\end{array}$ & $\begin{array}{c}-0.20 \\
(0.72)\end{array}$ & $\begin{array}{c}0.27 \\
(0.04)\end{array}$ & $\begin{array}{c}0.04 \\
(0.90)\end{array}$ & $\begin{array}{c}-0.15 \\
(0.61)\end{array}$ & $\begin{array}{l}-0.80 \\
(0.02)\end{array}$ & $\begin{array}{c}-0.08 \\
(0.91) \\
\end{array}$ & $\begin{array}{c}0.34 \\
(0.11)\end{array}$ & $\begin{array}{c}0.15 \\
(0.65)\end{array}$ & $\begin{array}{c}0.27 \\
(0.72)\end{array}$ & $\begin{array}{c}0.06 \\
(0.79)\end{array}$ \\
\hline$\beta_{M}^{N L}$ & $\begin{array}{c}-0.99 \\
(<0.01)\end{array}$ & $\begin{array}{c}-0.79 \\
(<0.01)\end{array}$ & $\begin{array}{c}-0.30 \\
(<0.01)\end{array}$ & $\begin{array}{c}-0.64 \\
(<0.01)\end{array}$ & $\begin{array}{c}-0.76 \\
(<0.01)\end{array}$ & $\begin{array}{c}-0.46 \\
(<0.01)\end{array}$ & $\begin{array}{c}-1.35 \\
(<0.01)\end{array}$ & $\begin{array}{c}-0.43 \\
(<0.01)\end{array}$ & $\begin{array}{c}-0.68 \\
(<0.01)\end{array}$ & $\begin{array}{c}-0.61 \\
(<0.01)\end{array}$ & $\begin{array}{c}-0.71 \\
(<0.01)\end{array}$ \\
\hline$\beta_{S M B}^{N L}$ & $\begin{array}{c}0.28 \\
(0.55)\end{array}$ & $\begin{array}{c}0.42 \\
(0.33)\end{array}$ & $\begin{array}{l}-0.06 \\
(0.67)\end{array}$ & $\begin{array}{c}0.11 \\
(0.72)\end{array}$ & $\begin{array}{c}0.12 \\
(0.61)\end{array}$ & $\begin{array}{c}0.61 \\
(0.05)\end{array}$ & $\begin{array}{l}-1.36 \\
(0.07)\end{array}$ & $\begin{array}{c}0.17 \\
(0.37)\end{array}$ & $\begin{array}{c}0.41 \\
(0.17)\end{array}$ & $\begin{array}{l}-0.25 \\
(0.53)\end{array}$ & $\begin{array}{c}0.37 \\
(0.07)\end{array}$ \\
\hline$\beta_{H L M}^{N L}$ & $\begin{array}{l}-0.26 \\
(0.47)\end{array}$ & $\begin{array}{l}-0.57 \\
(0.36)\end{array}$ & $\begin{array}{c}0.05 \\
(0.72)\end{array}$ & $\begin{array}{l}-0.44 \\
(0.09)\end{array}$ & $\begin{array}{l}-0.04 \\
(0.87)\end{array}$ & $\begin{array}{l}-0.61 \\
(0.02)\end{array}$ & $\begin{array}{l}-0.25 \\
(0.70)\end{array}$ & $\begin{array}{l}-0.15 \\
(0.45)\end{array}$ & $\begin{array}{c}-0.98 \\
(<0.01)\end{array}$ & $\begin{array}{l}-0.77 \\
(0.08)\end{array}$ & $\begin{array}{l}-0.18 \\
(0.31)\end{array}$ \\
\hline$\beta_{M O M}^{N L}$ & $\begin{array}{c}-0.31 \\
(0.16) \\
\end{array}$ & $\begin{array}{l}-0.41 \\
(0.11)\end{array}$ & $\begin{array}{l}-0.02 \\
(0.75)\end{array}$ & $\begin{array}{c}0.02 \\
(0.89)\end{array}$ & $\begin{array}{c}0.12 \\
(0.36)\end{array}$ & $\begin{array}{l}-0.11 \\
(0.51)\end{array}$ & $\begin{array}{c}0.75 \\
(0.04)\end{array}$ & $\begin{array}{l}-0.01 \\
(0.99)\end{array}$ & $\begin{array}{l}-0.25 \\
(0.10) \\
\end{array}$ & $\begin{array}{c}-0.81 \\
(<0.01)\end{array}$ & $\begin{array}{l}-0.04 \\
(0.73)\end{array}$ \\
\hline$\beta_{E R}^{N L}$ & $\begin{array}{c}1.01 \\
(<0.01)\end{array}$ & $\begin{array}{l}-0.09 \\
(0.88) \\
\end{array}$ & $\begin{array}{c}0.42 \\
(<0.01)\end{array}$ & $\begin{array}{c}0.83 \\
(0.01)\end{array}$ & $\begin{array}{c}0.77 \\
(0.02)\end{array}$ & $\begin{array}{c}0.73 \\
(0.05)\end{array}$ & $\begin{array}{c}0.64 \\
(0.38)\end{array}$ & $\begin{array}{c}0.91 \\
(<0.01)\end{array}$ & $\begin{array}{l}-0.81 \\
(0.01)\end{array}$ & $\begin{array}{c}0.68 \\
(0.29)\end{array}$ & $\begin{array}{c}0.95 \\
(<0.01)\end{array}$ \\
\hline$\beta_{S O V}^{N L}$ & $\begin{array}{l}-0.10 \\
(0.51) \\
\end{array}$ & $\begin{array}{l}-0.15 \\
(0.19) \\
\end{array}$ & $\begin{array}{c}-0.04 \\
(0.29) \\
\end{array}$ & $\begin{array}{l}-0.11 \\
(0.23)\end{array}$ & $\begin{array}{l}-0.12 \\
(0.02) \\
\end{array}$ & $\begin{array}{c}0.05 \\
(0.45) \\
\end{array}$ & $\begin{array}{c}-0.35 \\
(<0.01) \\
\end{array}$ & $\begin{array}{c}-0.12 \\
(<0.01)\end{array}$ & $\begin{array}{l}-0.10 \\
(0.01) \\
\end{array}$ & $\begin{array}{c}-0.30 \\
(<0.01)\end{array}$ & $\begin{array}{c}-0.12 \\
(0.02) \\
\end{array}$ \\
\hline \multicolumn{12}{|c|}{ Transition Parameters } \\
\hline$\gamma$ & 62.02 & 9585 & 1452 & 43121 & 3919 & 8003 & 17418 & 5688 & 49.84 & 1296 & 3.72 \\
\hline$c$ & 43.08 & 51.09 & 32.44 & 42.62 & 40.1 & 41.56 & 42.59 & 41.04 & 45.16 & 62.18 & 43.54 \\
\hline
\end{tabular}

Note: This table reports the results from the estimation of Eq. (3) over 14/12/2007-08/03/2013:

$$
\begin{aligned}
R_{p, t}=\alpha^{L}+\beta_{M}^{L} & R_{M, t}+\beta_{S M B}^{L} R_{S M B, t-1}+\beta_{H M L}^{L} R_{H M L, t-1}+\beta_{M O M}^{L} R_{M O M, t-1}+\beta_{E R}^{L} R_{E R, t}+\beta_{S O V}^{L} R_{S O V, t} \\
& +g\left(v_{t-\tau} ; \gamma, c\right)\left[\alpha^{N L}+\beta_{M}^{N L} R_{M, t}+\beta_{S M B}^{N L} R_{S M B, t-1}+\beta_{H M L}^{N L} R_{H M L, t-1}+\beta_{M O M}^{N L} R_{M O M, t-1}\right. \\
& \left.+\beta_{E R}^{N L} R_{E R, t}+\beta_{S O V}^{N L} R_{S O V, t}\right]+\varepsilon_{p, t}
\end{aligned}
$$

where for $i=L$ (Linear part) or NL (Nonlinear part), $\beta_{M}^{i}$ and $\beta_{S M B}^{i}, \beta_{H M L}^{i}, \beta_{M O M}^{i}$ denote coefficients of, respectively, the market factor and the three U.S. Fama and French and Carhart factors: small minus big firms returns, returns of high book to market firms minus low ones and a momentum factor. The SMB, HML, and MOM U.S. factors are lagged to account for non-synchronous trading with the U.S.. $\beta_{E R}^{i}$ is the coefficient on the change in the logged USD/EUR exchange rate. $\beta_{\text {sov }}^{i}$ is the coefficient on the average change in GIP Sovereign CDS spreads. $\gamma$ is the slope parameter and $c$ is the threshold value of the VSTOXX. Marginal significance levels based on Newey-West covariance estimator are given in parentheses. Country codes are given at the beginning of Section 3.2.

For Greece, the negative linear impact $\left(\beta_{S O V}^{L}\right)$ is particularly large - which may explain why Arnold (2012) mainly captures this effect - though it does not appear to be further strengthened when the VSTOXX increases sharply. But for many eurozone countries the nonlinear effect is significant and sizeable: it is mostly when the VSTOXX rises above its threshold $c$ that the high risk aversion and the European economic downturn cause banks stock returns to plummet in reaction to a hike in GIP sovereign CDSs. 
Not surprisingly the Irish and Portuguese banks are amongst the most severely affected, a result again consistent with Arnold (2012). But, in line with the conclusions of Bhanot et al. (2014) and Grammatikos and Vermeulen (2012), we find that some shift contagion appears to spread the negative impact of the GIP sovereign risks outside the GIP and, in particular, it hits the French, Italian, Dutch and Austrian banks for which the estimates of $\beta_{S O V}^{N L}$ are largely negative. ${ }^{18}$

The other results obtained with the VSTOXX as the transition variable are also broadly consistent with the preliminary linear results from the estimation of equation (2). In particular, in the linear part of equation (3) the $\beta$ of the market factor $\left(\beta_{M}^{L}\right)$ is above one for most countries, though it tends to decrease $\left(\beta_{M}^{N L}<0\right)$ when the VSTOXX increases above its threshold. Similarly the coefficient for the exchange rate is consistently negative $\left(\beta_{E R}^{L}<0\right.$ and $\left.\beta_{E R}^{L}+\beta_{E R}^{N L}<0\right)$ for these eurozone countries, though its size is often reduced $\left(\beta_{E R}^{N L}>0\right)$ when the VSTOXX surges.

Table 3.2 displays the results of the nonlinear regressions for eurozone countries when the transition variable is the iTraxx financials index.

As regards the impact of Sovereign risks, the results confirm again that in all the eurozone under study banks' returns have at some point been negatively impacted by the rise in GIP sovereign CDS spreads. Indeed, either $\beta_{S O V}^{L}$ and/or $\beta_{S O V}^{N L}$ are negative for all these eurozone countries and their sum is always below zero: when the iTraxx financials index surges above a threshold (c), estimated between 107 (for The Netherlands) and 193 (for Germany), eurozone banks stock returns drop in response to a rise in the sovereign risk of the three countries most adversely hit by the European sovereign debt crisis. For Germany and Finland this negative impact is relatively small $\left(\beta_{S O V}^{L} \geq-0.05\right)$ and limited to the linear part of the model. For Greece, Portugal, Italy, Spain, France, Belgium and Austria the negative impact of the sovereign GIP risk is more sizeable, but limited here to the linear part of the model. However for Ireland and the Netherlands the nonlinear effect is both significant and relatively large: it is mostly when the iTraxx Financials index rises above its threshold $c$ that the financial stress in the eurozone causes the banks stock returns from these two countries to plummet in reaction to a hike in GIP sovereign CDSs. Not surprisingly the Irish banks are the most severely affected.

Otherwise, the results obtained for eurozone countries with the iTraxx Financials index as the transition variable are broadly consistent with the preliminary linear results from the estimation of equation (2). In particular, in the linear part of equation (3) the $\beta$ of the market factor $\left(\beta_{M}^{L}\right)$ is above one for most countries and the coefficient for the exchange rate $\left(\beta_{E R}^{L}\right.$ when the iTraxx is low and $\beta_{E R}^{L}+\beta_{E R}^{N L}$ when it is high) is consistently negative for these eurozone countries. The magnitude of the coefficient for the exchange rate increases during periods of stress in the European banking system (when the iTraxx financials index is high), with estimates of $\beta_{E R}^{N L}$ that are significantly negative, except for Ireland and the Netherlands (non significant

${ }^{18}$ For Austrian banks the large estimate (-0.30) may appear puzzling. However the estimated threshold is especially high for Austria (62.18) and is mostly crossed in the aftermath of Lehman Brothers failure. 
coefficients). In other terms, an appreciation of the USD against the Euro deteriorates more the stock market performance of eurozone banks when the stress in the European banking system is already high.

Table 3.2: Results of the nonlinear estimations of the multifactor model of bank returns for the eurozone countries with the lagged iTraxx Financials index as the transition variable

\begin{tabular}{|c|c|c|c|c|c|c|c|c|c|c|c|}
\hline & $B E$ & $D E$ & $E S$ & $F N$ & $F R$ & $G R$ & $I E$ & $I T$ & $N E$ & $O E$ & $P T$ \\
\hline \multicolumn{12}{|c|}{ Linear Parameters } \\
\hline$\alpha^{L}$ & $\begin{array}{c}-0.13 \\
(0.24) \\
\end{array}$ & $\begin{array}{c}-0.07 \\
(0.25)\end{array}$ & $\begin{array}{c}-0.08 \\
(0.12) \\
\end{array}$ & $\begin{array}{c}-0.02 \\
(0.78)\end{array}$ & $\begin{array}{c}-0.06 \\
(0.42)\end{array}$ & $\begin{array}{c}-0.16 \\
(0.09)\end{array}$ & $\begin{array}{c}-0.50 \\
(0.03)\end{array}$ & $\begin{array}{c}-0.09 \\
(0.14)\end{array}$ & $\begin{array}{c}-0.40 \\
(<0.01)\end{array}$ & $\begin{array}{c}-0.01 \\
(0.91) \\
\end{array}$ & $\begin{array}{c}-0.07 \\
(0.26) \\
\end{array}$ \\
\hline$\beta_{M}^{L}$ & $\begin{array}{c}1.36 \\
(<0.01)\end{array}$ & $\begin{array}{c}1.46 \\
(<0.01)\end{array}$ & $\begin{array}{c}1.12 \\
(<0.01)\end{array}$ & $\begin{array}{c}0.97 \\
(<0.01)\end{array}$ & $\begin{array}{c}1.10 \\
(<0.01)\end{array}$ & $\begin{array}{c}0.81 \\
(<0.01)\end{array}$ & $\begin{array}{c}2.38 \\
(<0.01) \\
\end{array}$ & $\begin{array}{c}0.96 \\
(<0.01)\end{array}$ & $\begin{array}{c}1.53 \\
(<0.01)\end{array}$ & $\begin{array}{c}1.21 \\
(<0.01)\end{array}$ & $\begin{array}{c}0.60 \\
(<0.01)\end{array}$ \\
\hline$\beta_{S M B}^{L}$ & $\begin{array}{c}-0.05 \\
(0.79) \\
\end{array}$ & $\begin{array}{c}-0.09 \\
(0.43)\end{array}$ & $\begin{array}{c}-0.11 \\
(0.21)\end{array}$ & $\begin{array}{c}0.02 \\
(0.90) \\
\end{array}$ & $\begin{array}{c}-0.22 \\
(0.09)\end{array}$ & $\begin{array}{c}-0.07 \\
(0.57)\end{array}$ & $\begin{array}{c}-0.02 \\
(0.97)\end{array}$ & $\begin{array}{c}-0.02 \\
(0.87)\end{array}$ & $\begin{array}{c}0.33 \\
(0.19)\end{array}$ & $\begin{array}{c}-0.08 \\
(0.44)\end{array}$ & $\begin{array}{c}0.02 \\
(0.81) \\
\end{array}$ \\
\hline$\beta_{H L M}^{L}$ & $\begin{array}{c}0.65 \\
(<0.01)\end{array}$ & $\begin{array}{c}0.15 \\
(0.23)\end{array}$ & $\begin{array}{c}0.28 \\
(<0.01)\end{array}$ & $\begin{array}{c}0.36 \\
(<0.01)\end{array}$ & $\begin{array}{c}0.51 \\
(<0.01)\end{array}$ & $\begin{array}{c}0.43 \\
(<0.01)\end{array}$ & $\begin{array}{c}0.90 \\
(0.05) \\
\end{array}$ & $\begin{array}{c}0.18 \\
(0.08)\end{array}$ & $\begin{array}{c}0.31 \\
(0.25)\end{array}$ & $\begin{array}{c}0.30 \\
(<0.01)\end{array}$ & $\begin{array}{c}0.28 \\
(<0.01)\end{array}$ \\
\hline$\beta_{M O M}^{L}$ & $\begin{array}{c}-0.34 \\
(<0.01)\end{array}$ & $\begin{array}{c}-0.09 \\
(0.10)\end{array}$ & $\begin{array}{l}-0.10 \\
(0.06) \\
\end{array}$ & $\begin{array}{c}-0.27 \\
(<0.01)\end{array}$ & $\begin{array}{l}-0.19 \\
(0.02)\end{array}$ & $\begin{array}{c}-0.13 \\
(0.06)\end{array}$ & $\begin{array}{c}-0.45 \\
(0.04) \\
\end{array}$ & $\begin{array}{c}-0.16 \\
(<0.01)\end{array}$ & $\begin{array}{c}-0.25 \\
(0.16)\end{array}$ & $\begin{array}{c}-0.27 \\
(<0.01)\end{array}$ & $\begin{array}{l}-0.08 \\
(0.10) \\
\end{array}$ \\
\hline$\beta_{E R}^{L}$ & $\begin{array}{c}-1.42 \\
(<0.01)\end{array}$ & $\begin{array}{c}-1.59 \\
(<0.01)\end{array}$ & $\begin{array}{c}-1.43 \\
(<0.01)\end{array}$ & $\begin{array}{c}-0.92 \\
(<0.01)\end{array}$ & $\begin{array}{c}-1.22 \\
(<0.01)\end{array}$ & $\begin{array}{c}-0.98 \\
(<0.01)\end{array}$ & $\begin{array}{c}-1.67 \\
(<0.01)\end{array}$ & $\begin{array}{c}-1.15 \\
(<0.01)\end{array}$ & $\begin{array}{c}-0.76 \\
(0.02)\end{array}$ & $\begin{array}{c}-1.48 \\
(<0.01)\end{array}$ & $\begin{array}{c}-0.76 \\
(<0.01)\end{array}$ \\
\hline$\beta_{S O V}^{L}$ & $\begin{array}{c}-0.09 \\
(<0.01)\end{array}$ & $\begin{array}{l}-0.04 \\
(0.02)\end{array}$ & $\begin{array}{c}-0.08 \\
(<0.01)\end{array}$ & $\begin{array}{l}-0.05 \\
(0.04)\end{array}$ & $\begin{array}{c}-0.07 \\
(<0.01)\end{array}$ & $\begin{array}{c}-0.25 \\
(<0.01)\end{array}$ & $\begin{array}{c}0.06 \\
(0.29)\end{array}$ & $\begin{array}{c}-0.07 \\
(<0.01)\end{array}$ & $\begin{array}{c}0.03 \\
(0.36)\end{array}$ & $\begin{array}{c}-0.08 \\
(<0.01)\end{array}$ & $\begin{array}{c}-0.10 \\
(<0.01)\end{array}$ \\
\hline \multicolumn{12}{|c|}{ Nonlinear Parameters } \\
\hline$\alpha^{N L}$ & $\begin{array}{c}0.11 \\
(0.59)\end{array}$ & $\begin{array}{c}0.03 \\
(0.78)\end{array}$ & $\begin{array}{c}0.20 \\
(0.04)\end{array}$ & $\begin{array}{c}0.16 \\
(0.21)\end{array}$ & $\begin{array}{c}0.06 \\
(0.71)\end{array}$ & $\begin{array}{c}0.06 \\
(0.85)\end{array}$ & $\begin{array}{c}0.41 \\
(0.16)\end{array}$ & $\begin{array}{c}0.03 \\
(0.84)\end{array}$ & $\begin{array}{c}0.36 \\
(0.01)\end{array}$ & $\begin{array}{c}-0.03 \\
(0.77)\end{array}$ & $\begin{array}{c}-0.08 \\
(0.62)\end{array}$ \\
\hline$\beta_{M}^{N L}$ & $\begin{array}{c}0.47 \\
(0.07)\end{array}$ & $\begin{array}{c}0.15 \\
(0.38)\end{array}$ & $\begin{array}{c}0.16 \\
(0.23)\end{array}$ & $\begin{array}{c}0.37 \\
(0.02)\end{array}$ & $\begin{array}{c}0.99 \\
(<0.01)\end{array}$ & $\begin{array}{c}-0.47 \\
(0.23)\end{array}$ & $\begin{array}{c}-1.24 \\
(<0.01)\end{array}$ & $\begin{array}{c}0.63 \\
(<0.01)\end{array}$ & $\begin{array}{c}-1.25 \\
(<0.01)\end{array}$ & $\begin{array}{c}0.17 \\
(0.25)\end{array}$ & $\begin{array}{c}0.18 \\
(0.30)\end{array}$ \\
\hline$\beta_{S M B}^{N L}$ & $\begin{array}{c}0.18 \\
(0.63)\end{array}$ & $\begin{array}{c}-0.05 \\
(0.81)\end{array}$ & $\begin{array}{c}-0.02 \\
(0.90)\end{array}$ & $\begin{array}{c}-0.08 \\
(0.73)\end{array}$ & $\begin{array}{c}0.31 \\
(0.25)\end{array}$ & $\begin{array}{c}0.09 \\
(0.86)\end{array}$ & $\begin{array}{c}0.30 \\
(0.64)\end{array}$ & $\begin{array}{c}-0.04 \\
(0.87)\end{array}$ & $\begin{array}{l}-0.25 \\
(0.40)\end{array}$ & $\begin{array}{c}0.36 \\
(0.11)\end{array}$ & $\begin{array}{c}-0.10 \\
(0.70)\end{array}$ \\
\hline$\beta_{H L M}^{N L}$ & $\begin{array}{c}-0.66 \\
(0.05)\end{array}$ & $\begin{array}{c}0.29 \\
(0.23)\end{array}$ & $\begin{array}{c}-0.07 \\
(0.64)\end{array}$ & $\begin{array}{c}-0.43 \\
(0.05)\end{array}$ & $\begin{array}{c}-0.28 \\
(0.34)\end{array}$ & $\begin{array}{l}-1.07 \\
(0.04)\end{array}$ & $\begin{array}{c}-0.98 \\
(0.08)\end{array}$ & $\begin{array}{c}0.03 \\
(0.90)\end{array}$ & $\begin{array}{c}-0.23 \\
(0.47)\end{array}$ & $\begin{array}{c}-0.43 \\
(0.02)\end{array}$ & $\begin{array}{c}-0.01 \\
(0.98)\end{array}$ \\
\hline$\beta_{M O M}^{N L}$ & $\begin{array}{c}-0.03 \\
(0.87)\end{array}$ & $\begin{array}{c}-0.07 \\
(0.60)\end{array}$ & $\begin{array}{c}-0.09 \\
(0.31)\end{array}$ & $\begin{array}{c}0.33 \\
(0.02)\end{array}$ & $\begin{array}{c}-0.27 \\
(0.14)\end{array}$ & $\begin{array}{c}0.17 \\
(0.56)\end{array}$ & $\begin{array}{c}0.21 \\
(0.45)\end{array}$ & $\begin{array}{c}0.07 \\
(0.64)\end{array}$ & $\begin{array}{c}0.16 \\
(0.39)\end{array}$ & $\begin{array}{c}0.09 \\
(0.51)\end{array}$ & $\begin{array}{c}-0.08 \\
(0.58)\end{array}$ \\
\hline$\beta_{E R}^{N L}$ & $\begin{array}{c}-1.44 \\
(<0.01)\end{array}$ & $\begin{array}{c}-0.97 \\
(<0.01)\end{array}$ & $\begin{array}{c}-0.72 \\
(<0.01)\end{array}$ & $\begin{array}{c}-1.04 \\
(<0.01)\end{array}$ & $\begin{array}{c}-2.04 \\
(<0.01)\end{array}$ & $\begin{array}{c}-1.67 \\
(<0.01)\end{array}$ & $\begin{array}{c}-0.14 \\
(0.82)\end{array}$ & $\begin{array}{c}-1.87 \\
(<0.01)\end{array}$ & $\begin{array}{c}0.39 \\
(0.27)\end{array}$ & $\begin{array}{c}-0.97 \\
(<0.01)\end{array}$ & $\begin{array}{c}-1.51 \\
(<0.01)\end{array}$ \\
\hline$\beta_{\text {SOV }}^{N L}$ & $\begin{array}{l}-0.01 \\
(0.84) \\
\end{array}$ & $\begin{array}{c}0.01 \\
(0.89) \\
\end{array}$ & $\begin{array}{c}0.01 \\
(0.97) \\
\end{array}$ & $\begin{array}{l}-0.04 \\
(0.33)\end{array}$ & $\begin{array}{l}-0.03 \\
(0.49) \\
\end{array}$ & $\begin{array}{c}0.07 \\
(0.22) \\
\end{array}$ & $\begin{array}{c}-0.20 \\
(<0.01)\end{array}$ & $\begin{array}{c}0.01 \\
(0.97) \\
\end{array}$ & $\begin{array}{l}-0.07 \\
(0.05)\end{array}$ & $\begin{array}{c}0.03 \\
(0.28) \\
\end{array}$ & $\begin{array}{c}0.06 \\
(0.13) \\
\end{array}$ \\
\hline \multicolumn{12}{|c|}{ Transition Parameters } \\
\hline$\gamma$ & 6.44 & 7.73 & 497.18 & 26.09 & 3.07 & 6.39 & 85747 & 4.90 & 7916 & 13243 & 4.92 \\
\hline & 158.02 & 193.87 & 154.91 & 164.79 & 170.78 & 186.44 & 111.03 & 156.50 & 107.05 & 161.79 & 177.05 \\
\hline
\end{tabular}

Note: This table reports the results from the estimation of Eq. (3) over 14/12/2007-08/03/2013:

$$
\begin{aligned}
R_{p, t}=\alpha^{L}+\beta_{M}^{L} & R_{M, t}+\beta_{S M B}^{L} R_{S M B, t-1}+\beta_{H M L}^{L} R_{H M L, t-1}+\beta_{M O M}^{L} R_{M O M, t-1}+\beta_{E R}^{L} R_{E R, t}+\beta_{S O V}^{L} R_{S O V, t} \\
& +g\left(v_{t-\tau} ; \gamma, c\right)\left[\alpha^{N L}+\beta_{M}^{N L} R_{M, t}+\beta_{S M B}^{N L} R_{S M B, t-1}+\beta_{H M L}^{N L} R_{H M L, t-1}+\beta_{M O M}^{N L} R_{M O M, t-1}\right. \\
& \left.+\beta_{E R}^{N L} R_{E R, t}+\beta_{S O V}^{N L} R_{S O V, t}\right]+\varepsilon_{p, t}
\end{aligned}
$$

where for $i=L$ (Linear part) or $N L$ (Nonlinear part), $\beta_{M}^{i}$ and $\beta_{S M B}^{i}, \beta_{H M L}^{i}, \beta_{M O M}^{i}$ denote coefficients of, respectively, the market factor and the three U.S. Fama and French and Carhart factors: small minus big firms returns, returns of high book to market firms minus low ones and a momentum factor. The SMB, HML, and MOM U.S. factors are lagged to account for non-synchronous trading with the U.S.. $\beta_{E R}^{i}$ is the coefficient on the change in the logged USD/EUR exchange rate. $\beta_{\text {sov }}^{i}$ is the coefficient on the average change in GIP Sovereign CDS spreads. $\gamma$ is the slope parameter and $c$ is the threshold value of the iTraxx Financials index. Marginal significance levels based on NeweyWest covariance estimator are given in parentheses. Country codes are given at the beginning of Section 3.2.

Table 3.3 displays the results of the nonlinear regressions for eurozone countries when the transition variable is the lagged return of the domestic banking sector $\left(R_{p, t-\tau}\right)$. With the exceptions of Belgium and 
Austria the estimates of the threshold $c$ are negative, meaning that the linear parameters of the model apply in bad times here, when the stock return of the domestic banking sector is negative. In "good" or better times, when the stock return of the banking sector remains above the threshold $c$, the coefficient of a given variable is given by the sum of its linear and nonlinear $\beta$ s.

Table 3.3: Results of the nonlinear estimations of the multifactor model of bank returns for eurozone countries with the lagged stock return as the transition variable

\begin{tabular}{|c|c|c|c|c|c|c|c|c|c|c|c|}
\hline & $B E$ & $D E$ & $E S$ & $F R$ & $F N$ & $G R$ & $I E$ & $I T$ & $N E$ & $O E$ & $P T$ \\
\hline \multicolumn{12}{|c|}{ Linear Parameters } \\
\hline$\alpha^{L}$ & $\begin{array}{c}-2.28 \\
(0.06) \\
\end{array}$ & $\begin{array}{l}-0.02 \\
(0.97) \\
\end{array}$ & $\begin{array}{c}-0.06 \\
(0.79) \\
\end{array}$ & $\begin{array}{l}-0.47 \\
(0.19) \\
\end{array}$ & $\begin{array}{c}1.16 \\
(0.17) \\
\end{array}$ & $\begin{array}{c}2.55 \\
(0.02) \\
\end{array}$ & $\begin{array}{l}-0.32 \\
(0.37) \\
\end{array}$ & $\begin{array}{c}0.29 \\
(0.26) \\
\end{array}$ & $\begin{array}{l}-1.53 \\
(0.07) \\
\end{array}$ & $\begin{array}{c}0.01 \\
(0.84) \\
\end{array}$ & $\begin{array}{l}-0.06 \\
(0.95) \\
\end{array}$ \\
\hline$\beta_{M}^{L}$ & $\begin{array}{c}1.25 \\
(<0.01)\end{array}$ & $\begin{array}{c}0.90 \\
(0.10)\end{array}$ & $\begin{array}{c}0.95 \\
(<0.01)\end{array}$ & $\begin{array}{c}1.06 \\
(<0.01)\end{array}$ & $\begin{array}{c}1.67 \\
(<0.01)\end{array}$ & $\begin{array}{l}-1.18 \\
(0.29) \\
\end{array}$ & $\begin{array}{c}1.13 \\
(<0.01)\end{array}$ & $\begin{array}{c}0.75 \\
(<0.01)\end{array}$ & $\begin{array}{c}1.57 \\
(<0.01)\end{array}$ & $\begin{array}{c}1.27 \\
(<0.01)\end{array}$ & $\begin{array}{c}2.69 \\
(<0.01)\end{array}$ \\
\hline$\beta_{S M B}^{L}$ & $\begin{array}{c}-0.06 \\
(0.88)\end{array}$ & $\begin{array}{c}0.38 \\
(0.48)\end{array}$ & $\begin{array}{c}-0.48 \\
(0.03) \\
\end{array}$ & $\begin{array}{c}0.44 \\
(0.10)\end{array}$ & $\begin{array}{c}-0.65 \\
(0.38) \\
\end{array}$ & $\begin{array}{l}-0.28 \\
(0.86)\end{array}$ & $\begin{array}{l}-0.46 \\
(0.35)\end{array}$ & $\begin{array}{l}-0.07 \\
(0.75)\end{array}$ & $\begin{array}{c}-1.91 \\
(<0.01)\end{array}$ & $\begin{array}{c}0.02 \\
(0.79) \\
\end{array}$ & $\begin{array}{c}2.73 \\
(0.08) \\
\end{array}$ \\
\hline$\beta_{H L M}^{L}$ & $\begin{array}{c}0.60 \\
(0.12) \\
\end{array}$ & $\begin{array}{c}-0.03 \\
(0.94) \\
\end{array}$ & $\begin{array}{c}0.43 \\
(0.06) \\
\end{array}$ & $\begin{array}{c}-0.04 \\
(0.90) \\
\end{array}$ & $\begin{array}{c}1.48 \\
(0.01) \\
\end{array}$ & $\begin{array}{c}1.62 \\
(0.22) \\
\end{array}$ & $\begin{array}{c}0.75 \\
(0.04) \\
\end{array}$ & $\begin{array}{l}-0.03 \\
(0.92) \\
\end{array}$ & $\begin{array}{c}1.60 \\
(<0.01)\end{array}$ & $\begin{array}{c}0.15 \\
(0.09) \\
\end{array}$ & $\begin{array}{c}4.35 \\
(<0.01) \\
\end{array}$ \\
\hline$\beta_{M O M}^{L}$ & $\begin{array}{l}-0.48 \\
(0.04)\end{array}$ & $\begin{array}{c}-1.08 \\
(<0.01)\end{array}$ & $\begin{array}{c}-0.09 \\
(0.55)\end{array}$ & $\begin{array}{c}-0.62 \\
(<0.01)\end{array}$ & $\begin{array}{c}0.49 \\
(0.18)\end{array}$ & $\begin{array}{l}-1.61 \\
(0.03)\end{array}$ & $\begin{array}{c}-0.05 \\
(0.81)\end{array}$ & $\begin{array}{c}-0.12 \\
(0.41)\end{array}$ & $\begin{array}{c}0.46 \\
(0.05)\end{array}$ & $\begin{array}{c}-0.23 \\
(<0.01)\end{array}$ & $\begin{array}{c}-4.17 \\
(<0.01) \\
\end{array}$ \\
\hline$\beta_{E R}^{L}$ & $\begin{array}{c}-1.20 \\
(<0.01)\end{array}$ & $\begin{array}{c}-0.86 \\
(0.11) \\
\end{array}$ & $\begin{array}{c}-1.72 \\
(<0.01) \\
\end{array}$ & $\begin{array}{l}-1.29 \\
(0.02) \\
\end{array}$ & $\begin{array}{c}-0.59 \\
(0.49) \\
\end{array}$ & $\begin{array}{l}-1.99 \\
(0.09) \\
\end{array}$ & $\begin{array}{c}-1.35 \\
(<0.01) \\
\end{array}$ & $\begin{array}{c}-2.50 \\
(<0.01) \\
\end{array}$ & $\begin{array}{c}1.75 \\
(<0.01) \\
\end{array}$ & $\begin{array}{c}-1.79 \\
(<0.01)\end{array}$ & $\begin{array}{c}-6.75 \\
(<0.01) \\
\end{array}$ \\
\hline$\beta_{S O V}^{L}$ & $\begin{array}{c}-0.14 \\
(0.05)\end{array}$ & $\begin{array}{c}-0.25 \\
(0.17) \\
\end{array}$ & $\begin{array}{c}-0.17 \\
(<0.01)\end{array}$ & $\begin{array}{c}-0.21 \\
(<0.01)\end{array}$ & $\begin{array}{c}-0.22 \\
(0.08) \\
\end{array}$ & $\begin{array}{c}-0.40 \\
(0.06) \\
\end{array}$ & $\begin{array}{l}-0.12 \\
(0.06) \\
\end{array}$ & $\begin{array}{c}-0.14 \\
(<0.01)\end{array}$ & $\begin{array}{c}-0.01 \\
(0.95) \\
\end{array}$ & $\begin{array}{c}-0.07 \\
(<0.01)\end{array}$ & $\begin{array}{c}-0.26 \\
(<0.01) \\
\end{array}$ \\
\hline \multicolumn{12}{|c|}{ Nonlinear Parameters } \\
\hline$\alpha^{N L}$ & $\begin{array}{c}5.57 \\
(0.07)\end{array}$ & $\begin{array}{c}-0.02 \\
(0.97)\end{array}$ & $\begin{array}{c}0.07 \\
(0.76)\end{array}$ & $\begin{array}{c}0.51 \\
(0.17)\end{array}$ & $\begin{array}{l}-1.16 \\
(0.17)\end{array}$ & $\begin{array}{c}-2.78 \\
(0.01)\end{array}$ & $\begin{array}{c}0.19 \\
(0.67)\end{array}$ & $\begin{array}{c}-0.37 \\
(0.16)\end{array}$ & $\begin{array}{c}1.39 \\
(0.09)\end{array}$ & $\begin{array}{l}-1.16 \\
(0.12)\end{array}$ & $\begin{array}{c}-0.03 \\
(0.97)\end{array}$ \\
\hline$\beta_{M}^{N L}$ & $\begin{array}{c}0.74 \\
(0.33) \\
\end{array}$ & $\begin{array}{c}0.68 \\
(0.22) \\
\end{array}$ & $\begin{array}{c}0.30 \\
(0.14) \\
\end{array}$ & $\begin{array}{c}0.42 \\
(0.25) \\
\end{array}$ & $\begin{array}{l}-0.62 \\
(0.08) \\
\end{array}$ & $\begin{array}{c}2.01 \\
(0.08) \\
\end{array}$ & $\begin{array}{c}0.86 \\
(0.04) \\
\end{array}$ & $\begin{array}{c}0.54 \\
(0.04) \\
\end{array}$ & $\begin{array}{c}-0.90 \\
(0.01) \\
\end{array}$ & $\begin{array}{c}0.20 \\
(0.51)\end{array}$ & $\begin{array}{c}-2.00 \\
(<0.01) \\
\end{array}$ \\
\hline$\beta_{S M B}^{N L}$ & $\begin{array}{c}0.28 \\
(0.77) \\
\end{array}$ & $\begin{array}{l}-0.50 \\
(0.35) \\
\end{array}$ & $\begin{array}{c}0.47 \\
(0.05)\end{array}$ & $\begin{array}{l}-0.69 \\
(0.02) \\
\end{array}$ & $\begin{array}{c}0.65 \\
(0.39) \\
\end{array}$ & $\begin{array}{c}0.25 \\
(0.88) \\
\end{array}$ & $\begin{array}{c}1.24 \\
(0.04) \\
\end{array}$ & $\begin{array}{c}0.07 \\
(0.79) \\
\end{array}$ & $\begin{array}{c}2.17 \\
(<0.01)\end{array}$ & $\begin{array}{c}0.15 \\
(0.83) \\
\end{array}$ & $\begin{array}{c}-2.71 \\
(0.08) \\
\end{array}$ \\
\hline$\beta_{H L M}^{N L}$ & $\begin{array}{l}-0.45 \\
(0.63) \\
\end{array}$ & $\begin{array}{c}0.28 \\
(0.59) \\
\end{array}$ & $\begin{array}{l}-0.25 \\
(0.29)\end{array}$ & $\begin{array}{c}0.54 \\
(0.07)\end{array}$ & $\begin{array}{l}-1.20 \\
(0.05)\end{array}$ & $\begin{array}{l}-1.36 \\
(0.30) \\
\end{array}$ & $\begin{array}{l}-0.87 \\
(0.08)\end{array}$ & $\begin{array}{c}0.25 \\
(0.37) \\
\end{array}$ & $\begin{array}{c}-1.58 \\
(<0.01)\end{array}$ & $\begin{array}{c}0.51 \\
(0.30)\end{array}$ & $\begin{array}{c}-4.09 \\
(<0.01) \\
\end{array}$ \\
\hline$\beta_{M O M}^{N L}$ & $\begin{array}{c}0.27 \\
(0.61) \\
\end{array}$ & $\begin{array}{c}1.03 \\
(0.01) \\
\end{array}$ & $\begin{array}{l}-0.05 \\
(0.75) \\
\end{array}$ & $\begin{array}{c}0.42 \\
(0.04) \\
\end{array}$ & $\begin{array}{c}-0.70 \\
(0.06) \\
\end{array}$ & $\begin{array}{c}1.48 \\
(0.05) \\
\end{array}$ & $\begin{array}{l}-0.57 \\
(0.04) \\
\end{array}$ & $\begin{array}{c}0.01 \\
(0.98) \\
\end{array}$ & $\begin{array}{c}-0.66 \\
(<0.01)\end{array}$ & $\begin{array}{l}-0.35 \\
(0.26) \\
\end{array}$ & $\begin{array}{c}4.06 \\
(<0.01) \\
\end{array}$ \\
\hline$\beta_{E R}^{N L}$ & $\begin{array}{l}-1.98 \\
(0.03)\end{array}$ & $\begin{array}{l}-1.00 \\
(0.07)\end{array}$ & $\begin{array}{c}-0.01 \\
(0.98)\end{array}$ & $\begin{array}{l}-0.80 \\
(0.17)\end{array}$ & $\begin{array}{c}-0.68 \\
(0.43) \\
\end{array}$ & $\begin{array}{c}0.66 \\
(0.58)\end{array}$ & $\begin{array}{c}-0.82 \\
(0.15)\end{array}$ & $\begin{array}{c}0.64 \\
(0.03)\end{array}$ & $\begin{array}{c}-2.31 \\
(<0.01)\end{array}$ & $\begin{array}{l}-0.95 \\
(0.07) \\
\end{array}$ & $\begin{array}{c}5.54 \\
(<0.01)\end{array}$ \\
\hline$\beta_{S O V}^{N L}$ & $\begin{array}{c}0.09 \\
(0.54) \\
\end{array}$ & $\begin{array}{c}0.22 \\
(0.23) \\
\end{array}$ & $\begin{array}{c}0.11 \\
(0.01) \\
\end{array}$ & $\begin{array}{c}0.16 \\
(<0.01)\end{array}$ & $\begin{array}{c}0.17 \\
(0.18) \\
\end{array}$ & $\begin{array}{c}0.19 \\
(0.38) \\
\end{array}$ & $\begin{array}{c}0.07 \\
(0.35) \\
\end{array}$ & $\begin{array}{c}0.10 \\
(0.01) \\
\end{array}$ & $\begin{array}{c}-0.01 \\
(0.86) \\
\end{array}$ & $\begin{array}{c}0.23 \\
(0.06) \\
\end{array}$ & $\begin{array}{c}0.19 \\
(0.01) \\
\end{array}$ \\
\hline \multicolumn{12}{|c|}{ Transition Parameters } \\
\hline$\gamma$ & 0.63 & 186.5 & 910.5 & 705.4 & 21.04 & 49.47 & 6868 & 27939 & 2019 & 13.0 & 2519 \\
\hline$c$ & 2.62 & -5.61 & -2.90 & -3.48 & -5.62 & -7.86 & -2.04 & -2.98 & -5.90 & 5.39 & -6.39 \\
\hline
\end{tabular}

Note: This table reports the results from the estimation of Eq. (3) over 14/12/2007-08/03/2013:

$$
\begin{aligned}
R_{p, t}=\alpha^{L}+\beta_{M}^{L} & R_{M, t}+\beta_{S M B}^{L} R_{S M B, t-1}+\beta_{H M L}^{L} R_{H M L, t-1}+\beta_{M O M}^{L} R_{M O M, t-1}+\beta_{E R}^{L} R_{E R, t}+\beta_{S O V}^{L} R_{S O V, t} \\
& +g\left(v_{t-\tau} ; \gamma, c\right)\left[\alpha^{N L}+\beta_{M}^{N L} R_{M, t}+\beta_{S M B}^{N L} R_{S M B, t-1}+\beta_{H M L}^{N L} R_{H M L, t-1}\right. \\
& \left.+\beta_{M O M}^{N L} R_{M O M, t-1}+\beta_{E R}^{N L} R_{E R, t}+\beta_{S O V}^{N L} R_{S O V, t}\right]+\varepsilon_{p, t}
\end{aligned}
$$

where for $i=L$ (Linear part) or NL (Nonlinear part), $\beta_{M}^{i}$ and $\beta_{S M B}^{i}, \beta_{H M L}^{i}, \beta_{M O M}^{i}$ denote coefficients of, respectively, the market factor and the three U.S. Fama and French and Carhart factors: small minus big firms returns, returns of high book to market firms minus low ones and a momentum factor. The SMB, HML, and MOM U.S. factors are lagged to account for non-synchronous trading with the U.S.. $\beta_{E R}^{i}$ is the coefficient on the change in the logged USD/EUR exchange rate. $\beta_{\text {Sov }}^{i}$ is the coefficient on the average change in GIP Sovereign CDS spreads. $\gamma$ is the slope parameter and $c$ is the threshold value of the lagged return of the banking sector $\left(R_{p, t r \tau}\right)$. Marginal significance levels based on Newey-West covariance estimator are given in parentheses. Country codes are given at the beginning of Section 3.2 . 
Concerning the impact of sovereign risks, the results displayed in Table 3.3 show that, with the exception of Germany and the Netherlands ${ }^{19}$, in all the eurozone countries under study banks' returns have been negatively impacted by the rise in the sovereign CDS of Greece, Ireland and Portugal (GIP), with estimates for $\beta_{S O V}$ such as $\beta_{S O V}^{L}<0$ and (except for Austria) $\beta_{S O V}^{L}+\beta_{S O V}^{N L}<0$. As could be expected, the magnitude of the coefficient of GIP sovereign risk is larger in "bad" times (linear parameters here), than in "good" ones, with $\beta_{S O V}^{L}<\beta_{S O V}^{L}+\beta_{S O V}^{N L}$. This result is consistent with some kind of shift contagion for non GIP countries such as Spain, France, Italy and Austria, for which we find significantly negative estimates of $\beta_{S O V}^{L}$, which apply when lagged banks returns are below the threshold $c$, whereas during better times this negative impact is reduced $\left(\beta_{S O V}^{L}<\beta_{S O V}^{L}+\beta_{S O V}^{N L}<0\right)$ or even reversed for Austria (with $\beta_{S O V}^{L}+\beta_{S O V}^{N L}>0$ ). However for Austria the estimated threshold is highly positive (5.39\%), meaning that the sum of coefficients $\beta_{\text {SOV }}^{L}+\beta_{\text {SOV }}^{N L}$ only applies when the Austrian banking sector's stocks performed exceptionnally well. In other terms the Austrian banking sector may have occasionally benefited from the GIP sovereign debt crisis (perhaps through a kind of flight-to-quality effect), but only when it was already outperforming. Otherwise, the rise in the GIP sovereign risk had a negative effect on Austrian banks, as for all the eurozone countries under study.

The other results obtained with the lagged return of the banking sector $\left(R_{p, t-\tau}\right)$ as the transition variable are broadly consistent with the preliminary linear results from the estimation of equation (2). In particular, the coefficient for the exchange rate $\left(\beta_{E R}^{L}\right.$ in "bad times" and $\beta_{E R}^{L}+\beta_{E R}^{N L}$ in "good times") is mostly negative.

Table 3.4 displays the results of the nonlinear regressions for four non-eurozone countries for all three transition variables: the lagged VSTOXX, the lagged iTraxx financials index, the lagged stock return of the banking sector.

The four non-eurozone countries selected for the sake of comparison with the eurozone countries include the U.S., Switzerland and Japan, that may play the role of safe havens during crises, (Ranaldo and Söderlind, 2010; McCauley and McGuire, 2009) and the U.K. which is characterized by a highly developed financial sector and close links both with eurozone countries and with the U.S.. The results do not point at a flightto-quality phenomenon for Japan and Switzerland. Their currencies may have appreciated during the crises episodes, but their banking sectors do not appear to have benefited from the rise in GIP sovereign risk. $\beta_{S O V}^{L}$ is consistently negative for all three transition variables for Switzerland, and negative with the iTraxx as transition variable for Japan. With the VSTOXX as transition variable $\beta_{S O V}^{N L}$ is negative for both countries, meaning that some shift contagion may have occurred when the risk aversion rose above 48 or 55 . With the iTraxx or the lagged stock return as transition variables, $\beta_{S O V}^{N L}$ is either not significant or positive for Switzerland and Japan, but the sum of coefficients stays negative $\left(\beta_{S O V}^{L}+\beta_{S O V}^{N L} \leq 0\right)$.

\footnotetext{
${ }^{19}$ The precision of the estimates is too low for these two countries to be able to conclude that $\beta_{S O V}^{L}$ is significantly negative.
} 
Table 3.4: Results of the nonlinear estimations of the multifactor model of bank returns for non-eurozone countries

\begin{tabular}{|c|c|c|c|c|c|c|c|c|c|c|c|c|}
\hline \multirow{2}{*}{$\begin{array}{c}\begin{array}{c}\text { Transition } \\
\text { variable }\end{array} \\
\text { Country }\end{array}$} & \multicolumn{4}{|c|}{ Lagged VSTOXX } & \multicolumn{4}{|c|}{ Lagged iTraxx Fin. Index } & \multicolumn{4}{|c|}{ Lagged stock return } \\
\hline & $\mathrm{CH}$ & $G B$ & $J P$ & US & $\mathrm{CH}$ & $G B$ & $J P$ & $U S$ & $\mathrm{CH}$ & $G B$ & $J P$ & $U S$ \\
\hline \multicolumn{13}{|c|}{ Linear Parameters } \\
\hline$\alpha^{L}$ & $\begin{array}{l}-0.05 \\
(0.38)\end{array}$ & $\begin{array}{c}0.01 \\
(0.91)\end{array}$ & $\begin{array}{l}-0.04 \\
(0.38)\end{array}$ & $\begin{array}{l}-0.08 \\
(0.03)\end{array}$ & $\begin{array}{l}-0.06 \\
(0.33)\end{array}$ & $\begin{array}{c}-0.04 \\
(0.62)\end{array}$ & $\begin{array}{c}0.01 \\
(0.98)\end{array}$ & $\begin{array}{c}-0.13 \\
(<0.01)\end{array}$ & $\begin{array}{c}-0.43 \\
(0.63)\end{array}$ & $\begin{array}{l}-0.69 \\
(0.15)\end{array}$ & $\begin{array}{c}2.01 \\
(0.17)\end{array}$ & $\begin{array}{c}0.01 \\
(0.85)\end{array}$ \\
\hline$\beta_{M}^{L}$ & $\begin{array}{c}1.39 \\
(<0.01)\end{array}$ & $\begin{array}{c}1.63 \\
(<0.01)\end{array}$ & $\begin{array}{c}0.50 \\
(<0.01)\end{array}$ & $\begin{array}{c}1.32 \\
(<0.01)\end{array}$ & $\begin{array}{c}1.30 \\
(<0.01)\end{array}$ & $\begin{array}{c}1.30 \\
(<0.01)\end{array}$ & $\begin{array}{c}0.55 \\
(<0.01)\end{array}$ & $\begin{array}{c}1.00 \\
(<0.01)\end{array}$ & $\begin{array}{c}1.17 \\
(<0.01)\end{array}$ & $\begin{array}{c}0.33 \\
(0.10)\end{array}$ & $\begin{array}{c}0.16 \\
(0.63)\end{array}$ & $\begin{array}{c}1.16 \\
(<0.01)\end{array}$ \\
\hline$\beta_{S M B}^{L}$ & $\begin{array}{l}-0.11 \\
(0.13)\end{array}$ & $\begin{array}{l}-0.09 \\
(0.32)\end{array}$ & $\begin{array}{c}0.01 \\
(0.89)\end{array}$ & $\begin{array}{l}-0.08 \\
(0.38)\end{array}$ & $\begin{array}{l}-0.16 \\
(0.10)\end{array}$ & $\begin{array}{l}-0.30 \\
(0.07)\end{array}$ & $\begin{array}{c}-0.04 \\
(0.79)\end{array}$ & $\begin{array}{l}-0.07 \\
(0.53)\end{array}$ & $\begin{array}{c}0.52 \\
(0.50)\end{array}$ & $\begin{array}{c}0.16 \\
(0.66)\end{array}$ & $\begin{array}{l}-0.36 \\
(0.42)\end{array}$ & $\begin{array}{c}0.21 \\
(0.07)\end{array}$ \\
\hline$\beta_{H L M}^{L}$ & $\begin{array}{c}0.38 \\
(<0.01)\end{array}$ & $\begin{array}{c}0.43 \\
(<0.01)\end{array}$ & $\begin{array}{c}0.30 \\
(<0.01)\end{array}$ & $\begin{array}{c}1.46 \\
(<0.01)\end{array}$ & $\begin{array}{c}0.49 \\
(<0.01)\end{array}$ & $\begin{array}{c}0.53 \\
(<0.01)\end{array}$ & $\begin{array}{c}0.39 \\
(<0.01)\end{array}$ & $\begin{array}{c}2.39 \\
(<0.01)\end{array}$ & $\begin{array}{c}1.24 \\
(<0.01)\end{array}$ & $\begin{array}{c}0.35 \\
(0.29)\end{array}$ & $\begin{array}{c}1.60 \\
(<0.01)\end{array}$ & $\begin{array}{c}2.09 \\
(<0.01)\end{array}$ \\
\hline$\beta_{M O M}^{L}$ & $\begin{array}{c}-0.20 \\
(<0.01)\end{array}$ & $\begin{array}{c}-0.22 \\
(<0.01)\end{array}$ & $\begin{array}{c}-0.30 \\
(<0.01)\end{array}$ & $\begin{array}{c}-0.57 \\
(<0.01)\end{array}$ & $\begin{array}{c}-0.25 \\
(<0.01)\end{array}$ & $\begin{array}{c}-0.30 \\
(<0.01)\end{array}$ & $\begin{array}{c}-0.36 \\
(<0.01)\end{array}$ & $\begin{array}{c}-0.51 \\
(<0.01)\end{array}$ & $\begin{array}{l}-0.17 \\
(0.70)\end{array}$ & $\begin{array}{l}-0.17 \\
(0.35)\end{array}$ & $\begin{array}{l}-0.08 \\
(0.89)\end{array}$ & $\begin{array}{c}-0.58 \\
(<0.01)\end{array}$ \\
\hline$\beta_{E R}^{L}$ & $\begin{array}{c}-1.29 \\
(<0.01)\end{array}$ & $\begin{array}{c}-1.68 \\
(<0.01)\end{array}$ & $\begin{array}{l}-0.15 \\
(0.04)\end{array}$ & $\begin{array}{c}0.22 \\
(<0.01)\end{array}$ & $\begin{array}{c}-1.31 \\
(<0.01)\end{array}$ & $\begin{array}{c}-1.18 \\
(<0.01)\end{array}$ & $\begin{array}{c}0.10 \\
(0.50)\end{array}$ & $\begin{array}{c}0.28 \\
(<0.01)\end{array}$ & $\begin{array}{c}-2.76 \\
(<0.01)\end{array}$ & $\begin{array}{l}-0.39 \\
(0.16)\end{array}$ & $\begin{array}{c}0.36 \\
(0.14)\end{array}$ & $\begin{array}{c}0.21 \\
(<0.01)\end{array}$ \\
\hline$\beta_{S O V}^{L}$ & $\begin{array}{c}-0.02 \\
(0.07)\end{array}$ & $\begin{array}{c}-0.01 \\
(0.22)\end{array}$ & $\begin{array}{l}-0.01 \\
(0.62)\end{array}$ & $\begin{array}{c}0.03 \\
(0.02)\end{array}$ & $\begin{array}{l}-0.03 \\
(0.08)\end{array}$ & $\begin{array}{c}-0.03 \\
(0.08)\end{array}$ & $\begin{array}{l}-0.05 \\
(0.03)\end{array}$ & $\begin{array}{c}0.06 \\
(<0.01)\end{array}$ & $\begin{array}{c}-0.65 \\
(<0.01)\end{array}$ & $\begin{array}{c}-0.26 \\
(<0.01)\end{array}$ & $\begin{array}{c}-0.79 \\
(<0.01)\end{array}$ & $\begin{array}{c}0.03 \\
(<0.01)\end{array}$ \\
\hline \multicolumn{13}{|c|}{ Nonlinear Parameters } \\
\hline$\alpha^{N L}$ & $\begin{array}{c}1.03 \\
(0.09)\end{array}$ & $\begin{array}{c}-0.18 \\
(0.62)\end{array}$ & $\begin{array}{c}0.46 \\
(0.34)\end{array}$ & $\begin{array}{c}0.13 \\
(0.49)\end{array}$ & $\begin{array}{c}0.03 \\
(0.76)\end{array}$ & $\begin{array}{c}0.06 \\
(0.57)\end{array}$ & $\begin{array}{l}-0.01 \\
(0.94)\end{array}$ & $\begin{array}{c}0.14 \\
(0.07)\end{array}$ & $\begin{array}{c}0.38 \\
(0.67)\end{array}$ & $\begin{array}{c}0.70 \\
(0.15)\end{array}$ & $\begin{array}{l}-2.04 \\
(0.16)\end{array}$ & $\begin{array}{c}-0.97 \\
(<0.01)\end{array}$ \\
\hline$\beta_{M}^{N L}$ & $\begin{array}{l}-0.58 \\
(0.01)\end{array}$ & $\begin{array}{c}-0.78 \\
(<0.01)\end{array}$ & $\begin{array}{l}-0.34 \\
(0.04)\end{array}$ & $\begin{array}{l}-0.17 \\
(0.23)\end{array}$ & $\begin{array}{c}0.08 \\
(0.49)\end{array}$ & $\begin{array}{c}0.32 \\
(0.05)\end{array}$ & $\begin{array}{l}-0.18 \\
(0.11)\end{array}$ & $\begin{array}{c}0.66 \\
(<0.01)\end{array}$ & $\begin{array}{c}0.15 \\
(0.66)\end{array}$ & $\begin{array}{c}1.15 \\
(<0.01)\end{array}$ & $\begin{array}{c}0.26 \\
(0.44)\end{array}$ & $\begin{array}{c}0.05 \\
(0.75)\end{array}$ \\
\hline$\beta_{S M B}^{N L}$ & $\begin{array}{c}0.51 \\
(0.13)\end{array}$ & $\begin{array}{c}0.07 \\
(0.81)\end{array}$ & $\begin{array}{c}0.31 \\
(0.31)\end{array}$ & $\begin{array}{c}0.43 \\
(0.06)\end{array}$ & $\begin{array}{c}0.17 \\
(0.25)\end{array}$ & $\begin{array}{c}0.49 \\
(0.04)\end{array}$ & $\begin{array}{c}0.20 \\
(0.28)\end{array}$ & $\begin{array}{c}0.64 \\
(<0.01)\end{array}$ & $\begin{array}{l}-0.60 \\
(0.44)\end{array}$ & $\begin{array}{l}-0.27 \\
(0.47)\end{array}$ & $\begin{array}{c}0.44 \\
(0.35)\end{array}$ & $\begin{array}{l}-0.39 \\
(0.13)\end{array}$ \\
\hline$\beta_{H L M}^{N L}$ & $\begin{array}{c}0.12 \\
(0.72)\end{array}$ & $\begin{array}{c}-0.13 \\
(0.64)\end{array}$ & $\begin{array}{l}-0.17 \\
(0.54)\end{array}$ & $\begin{array}{c}1.77 \\
(<0.01)\end{array}$ & $\begin{array}{l}-0.37 \\
(0.01)\end{array}$ & $\begin{array}{l}-0.34 \\
(0.11)\end{array}$ & $\begin{array}{l}-0.22 \\
(0.14)\end{array}$ & $\begin{array}{c}-0.64 \\
(<0.01)\end{array}$ & $\begin{array}{c}-0.89 \\
(0.01)\end{array}$ & $\begin{array}{c}0.08 \\
(0.81)\end{array}$ & $\begin{array}{l}-1.36 \\
(0.02)\end{array}$ & $\begin{array}{c}0.20 \\
(0.46)\end{array}$ \\
\hline$\beta_{M O M}^{N L}$ & $\begin{array}{l}-0.35 \\
(0.06)\end{array}$ & $\begin{array}{c}-0.19 \\
(0.28)\end{array}$ & $\begin{array}{c}0.09 \\
(0.55)\end{array}$ & $\begin{array}{c}0.32 \\
(0.10)\end{array}$ & $\begin{array}{c}0.17 \\
(0.05)\end{array}$ & $\begin{array}{c}0.12 \\
(0.38)\end{array}$ & $\begin{array}{c}0.08 \\
(0.40)\end{array}$ & $\begin{array}{c}0.05 \\
(0.74)\end{array}$ & $\begin{array}{c}-0.03 \\
(0.94)\end{array}$ & $\begin{array}{l}-0.09 \\
(0.63)\end{array}$ & $\begin{array}{l}-0.23 \\
(0.69)\end{array}$ & $\begin{array}{c}0.12 \\
(0.53)\end{array}$ \\
\hline$\beta_{E R}^{N L}$ & $\begin{array}{c}-1.62 \\
(<0.01)\end{array}$ & $\begin{array}{c}0.60 \\
(0.09)\end{array}$ & $\begin{array}{c}1.08 \\
(<0.01)\end{array}$ & $\begin{array}{c}0.09 \\
(0.66)\end{array}$ & $\begin{array}{c}0.02 \\
(0.90)\end{array}$ & $\begin{array}{c}-0.82 \\
(<0.01)\end{array}$ & $\begin{array}{l}-0.09 \\
(0.60)\end{array}$ & $\begin{array}{c}0.15 \\
(0.27)\end{array}$ & $\begin{array}{c}1.48 \\
(0.06)\end{array}$ & $\begin{array}{c}-1.16 \\
(<0.01)\end{array}$ & $\begin{array}{c}-0.34 \\
(0.19)\end{array}$ & $\begin{array}{c}0.15 \\
(0.43)\end{array}$ \\
\hline$\beta_{S O V}^{N L}$ & $\begin{array}{l}-0.29 \\
(0.01)\end{array}$ & $\begin{array}{c}-0.09 \\
(<0.01)\end{array}$ & $\begin{array}{c}-0.23 \\
(0.03)\end{array}$ & $\begin{array}{c}0.05 \\
(0.11)\end{array}$ & $\begin{array}{l}-0.01 \\
(0.96)\end{array}$ & $\begin{array}{c}0.01 \\
(0.64)\end{array}$ & $\begin{array}{c}0.04 \\
(0.09)\end{array}$ & $\begin{array}{c}-0.03 \\
(0.04)\end{array}$ & $\begin{array}{c}0.63 \\
(<0.01)\end{array}$ & $\begin{array}{c}0.24 \\
(0.01)\end{array}$ & $\begin{array}{c}0.78 \\
(<0.01)\end{array}$ & $\begin{array}{c}0.05 \\
(0.30)\end{array}$ \\
\hline \multicolumn{13}{|c|}{ Transition Parameters } \\
\hline$\gamma$ & 723.95 & 8016.0 & 7.49 & 3.37 & 12641.70 & 5.27 & 27569.71 & 202.54 & 7.59 & 608.2 & 4.59 & 41.73 \\
\hline$c$ & 55.64 & 47.9 & 48.12 & 36.62 & 161.59 & 150.23 & 115.75 & 191.47 & -6.92 & -5.55 & -6.28 & 3.26 \\
\hline
\end{tabular}

Note: This table reports the results from the estimation of Eq. (3) over 14/12/2007-08/03/2013:

$$
\begin{aligned}
R_{p, t}=\alpha^{L}+\beta_{M}^{L} & R_{M, t}+\beta_{S M B}^{L} R_{S M B, t-1}+\beta_{H M L}^{L} R_{H M L, t-1}+\beta_{M O M}^{L} R_{M O M, t-1}+\beta_{E R}^{L} R_{E R, t}+\beta_{S O V}^{L} R_{S O V, t} \\
& +g\left(v_{t-\tau} ; \gamma, c\right)\left[\alpha^{N L}+\beta_{M}^{N L} R_{M, t}+\beta_{S M B}^{N L} R_{S M B, t-1}+\beta_{H M L}^{N L} R_{H M L, t-1}\right. \\
& \left.+\beta_{M O M}^{N L} R_{M O M, t-1}+\beta_{E R}^{N L} R_{E R, t}+\beta_{S O V}^{N L} R_{S O V, t}\right]+\varepsilon_{p, t}
\end{aligned}
$$

where for $i=L$ (Linear part) or NL (Nonlinear part), $\beta_{M}^{i}$ and $\beta_{S M B}^{i}, \beta_{H M L}^{i}, \beta_{M O M}^{i}$ denote the coefficients on, respectively, the global market factor and on three U.S. Fama and French and Carhart factors: small minus big firms returns, returns of high book-to-market firms minus low ones and a momentum factor. The SMB, HML and MOM U.S. factors are lagged for all countries, except the U.S., to account for time zone differences. $\beta_{E R}^{i}$ is the coefficient on the change in the logged USD/XXX exchange rate (for XXX equal to EUR for the U.S. and to either CHF or GBP or JPY for the other countries). $\gamma$ is the slope parameter and $c$ is the threshold value of the lagged transition variable. Marginal significance levels based on the Newey-West covariance estimator are given in parentheses. Country codes are given in section 3.2 . 
Similarly, the U.K. banking sector does not appear to benefit from the eurozone sovereign debt crisis, with $\beta_{S O V}^{L} \leq 0$ for all three transition variables, $\beta_{S O V}^{N L}<0$ with the VSTOXX as transition variable and $\beta_{\text {SOV }}^{L}+\beta_{\text {SOV }}^{N L} \leq 0$ when either the iTraxx or the lagged return is used as transion variable. The U.S. case is quite different: U.S. banks' equity returns appear to slightly benefit from the eurozone crisis, with $\beta_{S O V}^{L}>0$ for all the three transition variables, a result consistent with the preliminary linear results from the estimation of equation (2).

This difference between the U.S. on one hand and the U.K., Switzerland and Japan on the other hand might be explained by the fact that U.S. banks have the privilege of delivering international liquidity in the form of USD. Some other factors may also play a part (see section 4.1). In particular, from September 2011 to January 2015 the Swiss National Bank set a minimum exchange rate at CHF 1.20 per euro to prevent a further appreciation of the Swiss franc: it probably helped to reduce the attractivity of Swiss banks. ${ }^{20}$

Otherwise, the estimations are broadly in line with the results of the preliminary linear regressions. For instance, when significant the coefficient of the exchange rate in the linear part of the model is consistently negative $\left(\beta_{E R}^{L}<0\right)$, except for the U.S.: as expected an appreciation of the USD has an adverse effect on the stock returns of non U.S.-banks.

\section{Conclusion}

This paper provides some empirical evidence on contagion and on the impact of the eurozone sovereign debt crisis on European, Japanese and U.S. banks' stock returns during the period 2007-2013. More specifically, we use an explicit multifactor model for banks' equity returns and extend it to a nonlinear context to test for shift contagion and to assess to what extent the European sovereign debt crisis has exerted an influence on banks' equity returns. The use of an expanded version of the Carhart-Fama-French model allows us to control for the multiple common risk factors other than sovereign risk that may have impacted banks' stock returns over the period. Besides, we capture changes in parameters associated with shift contagion by estimating a STR extension of this multifactor model. The main advantages of this nonlinear approach are to allow for an endogenous definition of crisis periods and for smooth transitions between regimes. To assess the robustness of our results and to gain further insight into the variables that may trigger nonlinearities - and contagion - we use three different transition variables in our STR models: the VSTOXX, the iTraxx Financials index and the lagged banking stock return. Focusing on the impact of GIP (Greece, Ireland, and Portugal) sovereign CDS, we show that none of the European banks stock returns are spared by the European sovereign debt crisis and that shift contagion spreads and amplifies the negative impact of the GIP Sovereign debt crisis beyond the banks located in GIP countries. The spreading of this contagion effect depends on the transition variable involved in the amplification mechanism. With the VSTOXX as transition variable we find that the rise in the risk aversion on the European stock market amplifies the negative effect of the GIP Sovereign debt crisis for French, Italian, Dutch, Austrian, Swiss,

\footnotetext{
${ }^{20}$ To account for this change in the exchange rate policy of the Swiss National Bank we introduce a dummy in the regressions for Switzerland.
} 
British and Japanese banks. With the iTraxx Financials index as transition variable, we find that the stress on the European banking system increases the negative effect of the GIP Sovereign debt crisis on Dutch banks. With the lagged banks' stock returns as transition variable we find that poor past performances of domestic banks stocks tend to amplify the negative effect of the GIP Sovereign debt crisis on Spanish, French and Italian banks. These results contrast with the one found for U.S. banks, which seem to be unharmed by the direct impact of the European Sovereign debt crisis and even to slightly benefit from the European turmoil through what may be a kind of flight-to-quality effect. This finding may be related, among other things, to the delay with which European banks have, in the aftermath of Lehman Brothers' failure, cleaned up their balance sheets of distressed assets. It has probably put them at a disadvantage relatively to their U.S. counterparts.

In terms of policy implications, our results clearly suggest that a resolution of the sovereign debt crisis is a prerequisite to strengthen the stability of the European banking system. From this standpoint, there is a complementarity between the European banking union project and the implementation of mechanisms allowing the resolution of the sovereign debt crisis at the European level. More particularly, our findings echo the studies stressing the structural changes about the public debt management implied by the creation of the monetary union..$^{21}$

${ }^{21}$ See, for instance, Pisani-Ferry (2012), De Grauwe and Ji (2014) and Krugman (2013). 


\section{References}

Acharya, V.V., and Steffen, S. (2015), "The "greatest" carry trade ever? Understanding Eurozone bank risks", Journal of Financial Economics, 115(2), 2015-236.

Acharya, V.V., Drechsler, I., and Schnabl, P. (2014), “A Pyrrhic victory? bank bailouts and sovereign credit risk", The Journal of Finance, 69(6), 2689-2739..

Alter, A. and Beyer, A. (2014), "The dynamics of spillover effects during the european sovereign debt turmoil", Journal of Banking \& Finance, 42, 134-153.

Alter, A. and Schüler, Y.S. (2012), "Credit spread interdependencies of European states and banks during the financial crisis", Journal of Banking \& Finance, 36, 3444-3468.

Arnold, I.J.M. (2012),'Sovereign debt exposures and banking risks in the current EU financial crisis", Journal of Policy Modeling, 34, 906-920.

Bae K.-H., G.A. Karoly and R.M. Stulz (2003), "A new approach to measuring financial contagion”, The Review of Financial Studies, 16 (3), 717-763.

Beine M., A. Cosma and R. Vermeulen (2010), The dark side of global integration: Increasing tail dependence, Journal of Banking \& Finance, 34, 184-192.

Beirne, J. and Fratzscher, M. (2013), "The pricing of sovereign risk and contagion during the european sovereign debt crisis", Journal of International Money and Finance, 34, 60-82.

Bhanot, K., Burns, N., Hunter, D., and Williams, M. (2014), "News spillovers from the Greek debt crisis: Impact on the Eurozone Financial Sector", Journal of Banking \& Finance, 38, 51-63.

Bolton, P. and Jeanne, O. (2011), "Sovereign default risk and bank fragility in financially integrated economies", IMF Economic Review, 59(2), 162-94.

Brender, A., Pisani, F., and Gagna, E. (2013), The sovereign debt crisis, placing a curb on growth, Centre for European Policy Studies, Brussels, Belgium.

Caporin, M., Pelizzon, L., Ravazzolo, F., and Rigobon, R. (2013), "Measuring sovereign contagion in Europe", NBER Working Paper No. 18741, January.

Carhart, M. M. (1997), "On persistence in mutual fund performance", Journal of Finance, 52, 57-82.

Caruana, J. and Avdjiev, S. (2012), "Sovereign creditworthiness and financial stability: an international perspective", in Public debt, monetary policy and financial stability, Banque de France, Financial Stability Review, No. 16, 71-85.

Chan-Lau, J.A., Liu, E.X., and Schmittmann, J.M. (2015), "Equity returns in the banking sector in the wake of the great recession and the European sovereign debt crisis", Journal of Financial Stability, 16, 164172.

Committee on the Global Financial System (2011), The impact of sovereign credit risk on bank funding conditions, CGFS Papers No. 43, July.

De Bruyckere, V., Gerhardt, M., Schepens, G., and Vennet, R.V. (2013), "Bank/sovereign risk spillovers in the European debt crisis", Journal of Banking \& Finance, 37(12), 4793-4809.

De Grauwe, P. and Ji, Y. (2014), "How much fiscal discipline in a monetary union", Journal of Macroeconomics, 39 (Part B), 348-360.

Dieckmann, S. and Plank, T. (2012), "Default risk of advanced economies: an empirical analysis of credit default swaps during the financial crisis", Review of Finance, 16(4), 903-34.

Dumas, B. and B. Solnik (1995) "The world price of foreign exchange rate risk", Journal of Finance, 50, 445-480.

Eitrheim, O. and Teräsvirta, T. (1996), "Testing the adequacy of smooth transition autoregressive models, Journal of Econometrics, 74(1), 59-75.

Fama, E. F., and French, K. R. (1993), "Common risk factors in the returns on stocks and bonds", Journal of Financial Economics, 33, 3-56.

Fama, Eugene F., and Kenneth R. French (1996), "Multifactor explanations of asset pricing anomalies". Journal of Finance 51, 55-84.

Forbes, K. and Rigobon, R. (2001), "Measuring contagion: conceptual and empirical issues", in International financial contagion, edited by S. Claessens and K. Forbes, Kluwer Academic Press, 43-66.

Gerlach, S., Schulz, A., and Wolff, G.B. (2010), "Banking and sovereign risk in the euro area", Deutsche Bundesbank, Discussion Paper Series 1: Economic Studies No 09/2010.

Grammatikos, T. and Vermeulen, R. (2012), "Transmission of the financial and sovereign debt crises to the EMU: Stock prices, CDS spreads and exchange rates", Journal of International Money and Finance, 31, $517-533$. 
Gross, M. and Koky, C. (2013), "Measuring contagion potential among sovereigns and banks using a mixedcross-section GVAR”, ECB Working Paper Series, n¹570, August.

Hansen, B. E. (1996), "Inference when a nuisance parameter is not identified under the null hypothesis", Econometrica, 64(2), 413-430.

Hui, C.-H.,C.-F. Lo and C.-S. Lau (2013), Option-implied correlation between iTraxx Europe Financials and Non-Financials Indexes: A measure of spillover effect in European debt crisis, Journal of Banking \& Finance, 37, 3694-3703.

McCauley, R. and P. McGuire (2009), "Dollar Appreciation in 2008: safe haven, carry trades, dollar shortage and overhedging", BIS Quarterly Review, December.

Jansen, E.S., Teräsvirta, T. (1996), "Testing parameter constancy and super-exogeneity in econometric equations", Oxford Bulletin of Economics and Statistics, 58, 735-768.

IMF (2014), Global financial stability report, April 2014, Chapter 3.

Jegadeesh, N., and Titman, S. (1993), "Returns to buying winners and selling losers: implications for stock market efficiency", Journal of Finance 48, 65-91.

Krugman, P. (2013), "Currency regimes, capital flows, and Crises", IMF Economic Review, 62, 470-493..

Lintner, J. (1965), "The valuation of risk assets and the selection of risky investments in stock portfolios and capital budgets", Review of Economics and Statistics 47, 13-37.

Luukkonen, R., Saikkonen, P. andTeräsvirta, T. (1988), "Testing linearity against smooth transition autoregressive models", Biometrika 75, 491-499.

Mody, A. and Sandri, D. (2012), "The eurozone crisis: how banks and sovereigns came to be joined at the hip", Economic Policy, 27(70), 199-230.

Pisani-Ferry, J. (2012), "The Euro crisis and the new impossible trinity", Bruegel Policy Contribution, Issue 2012/01, January, Brussels.

Poirson, H. and Schmittmann, J. (2013), "Risk exposures and financial spillovers in tranquil and crisis times: bank-level evidence", IMF Working Paper, WP/13/142, June.

Ranaldo, A. and Söderling, P. (2010), Safe haven currencies, Review of Finance, 14, 385-407.

Rey, H. ( 2013), "Dilemma not trilemma dilemma not trilemma: The global financial cycle and monetary policy independence", Global Dimensions of Unconventional Monetary Policy Jackson Hole conference proceedings, Federal Reserve Bank of Kansas City, 285-333.

Ross, S.A. (1976), "The arbitrage theory of capital asset pricing", Journal of Economic Theory, 13, 341-360.

Sharpe, W.F. (1964), "Capital asset prices: a theory of market equilibrium under conditions of risk", Journal of Finance 19, 425-442.

Teräsvirta, T. (1994), "Specification, estimation, and evaluation of smooth transition autoregressive models", Journal of the American Statistical Association, 89, 208-218.

Teräsvirta, T. (1998), "Modelling economic relationships with smooth transition regressions", in the Handbook of applied economic statistics, edited by A. Ullah and D.E.A. Giles, 1998, Dekker, 507-552.

Teräsvirta, T. and Anderson, H.M. (1992), "Characterizing nonlinearities in business cycles using smooth transition autoregressive models", Journal of Applied Econometrics, 7 (S), S119-S136.

van Dijk, D., Teräsvirta T. and Franses, P.H. (2002), "Smooth transition autoregressive models - a survey of recent developments", Econometric Reviews, 21(1), 1-47.

van Rixtel, A. and Gasperini, G. (2013), "Financial crises and bank funding: recent experience in the euro area", BIS Working Papers No 406, March. 
Table A1: Summary statistics, in percentage

\begin{tabular}{|c|c|c|c|c|c|}
\hline Variable & Obs. & Mean & Std & Min & Max \\
\hline$R_{B E}$ & 1300 & $-0,102$ & 2,352 & $-25,416$ & 18,588 \\
\hline$R_{C H}$ & 1316 & $-0,048$ & 2,787 & $-10,820$ & 17,782 \\
\hline$R_{D E}$ & 1296 & $-0,064$ & 2,576 & $-16,474$ & 15,866 \\
\hline$R_{E S}$ & 1299 & $-0,024$ & 2,312 & $-11,498$ & 19,079 \\
\hline$R_{F N}$ & 1316 & 0,020 & 2,870 & $-18,202$ & 19,638 \\
\hline$R_{F R}$ & 1305 & $-0,038$ & 2,365 & $-13,419$ & 18,325 \\
\hline$R_{G B}$ & 1290 & 0,020 & 2,547 & $-4,464$ & 3,930 \\
\hline$R_{G R}$ & 1270 & $-0,251 * * *$ & 2,324 & $-16,309$ & 22,052 \\
\hline$R_{I E}$ & 1295 & $-0,187 * *$ & 2,614 & $-29,284$ & 29,930 \\
\hline$R_{I T}$ & 1293 & $-0,083$ & 2,287 & $-11,941$ & 15,801 \\
\hline$R_{J P}$ & 1314 & $-0,036$ & 2,713 & $-12,825$ & 14,117 \\
\hline$R_{N E}$ & 1305 & $-0,150$ & 3,493 & $-24,723$ & 15,161 \\
\hline$R_{O E}$ & 1315 & $-0,034$ & 2,604 & $-13,533$ & 14,312 \\
\hline$R_{P T}$ & 1304 & $-0,126 * * *$ & 2,325 & $-11,424$ & 12,795 \\
\hline$R_{U S}$ & 1316 & $-0,033$ & 2,935 & $-21,642$ & 19,350 \\
\hline$R_{M}$ & 1316 & $0.005 * *$ & 2,624 & -6.984 & 8.183 \\
\hline$R_{S M B}$ & 1316 & $0,017 * * *$ & 2,260 & $-3,790$ & 4,300 \\
\hline$R_{H M L}$ & 1316 & 0,006 & 2,758 & $-3,300$ & 3,950 \\
\hline$R_{M O M}$ & 1316 & $-0,021$ & 2,856 & $-8,300$ & 7,040 \\
\hline$R_{S O V}$ & 1316 & $0.474 * * *$ & 3,884 & -51.98 & 37.90 \\
\hline USD/EUR & 1316 & 0,005 & 2,179 & $-4,628$ & 3,733 \\
\hline GBP/USD & 1290 & 0,010 & 2,243 & $-4,464$ & 3,930 \\
\hline USD/CHF & 1316 & $-0,017$ & 2,289 & $-4,434$ & 8,430 \\
\hline USD/JPY & 1314 & $-0,024$ & 2,194 & $-5,395$ & 6,720 \\
\hline & & & & & \\
\hline
\end{tabular}

\section{Note:}

- $R_{p}$, for $p=B E, C H, D E, E S, F N, F R, G B, G R, I E, I T, J P, N E, O E, P T, U S$, is the excess stock return - in local currency - of the banking sector of country $p$. The summary statistics provided for the four factors of the Carhart model $\left(R_{M}, R_{S M B}, R_{H M L}, R_{M O M}\right)$ are based on the USD values of these variables.

- ***,**, and * denote significance at the $1 \%, 5 \%$, and $10 \%$ level respectively. 
Table A2: Testing for nonlinearity

\begin{tabular}{|c|c|c|c|c|c|c|}
\hline & $\square$ & $\mathrm{H}_{0}$ & $\mathrm{H}_{04}$ & $\mathrm{H}_{03}$ & $\mathrm{H}_{02}$ & Selected model \\
\hline \multicolumn{7}{|c|}{ With VSTOXX ${ }_{t-\tau}$ as transition variable } \\
\hline$B E$ & 3 & $3.1181 \mathrm{e}-12$ & $9.2183 \mathrm{e}-05$ & $1.0478 \mathrm{e}-02$ & $7.2984 \mathrm{e}-09$ & LSTR \\
\hline $\mathrm{CH}$ & 1 & $1.1014 \mathrm{e}-10$ & $7.0999 \mathrm{e}-02$ & $6.4856 \mathrm{e}-11$ & $2.4226 \mathrm{e}-02$ & ESTR / LSTR \\
\hline$D E$ & 1 & $3.0835 \mathrm{e}-32$ & $5.0615 \mathrm{e}-13$ & $4.1229 \mathrm{e}-18$ & $8.1707 \mathrm{e}-06$ & ESTR / LSTR \\
\hline$E S$ & 2 & $6.8344 \mathrm{e}-07$ & $4.2901 \mathrm{e}-03$ & $1.6166 \mathrm{e}-02$ & $8.0977 \mathrm{e}-05$ & LSTR \\
\hline$F N$ & 1 & $5.2818 \mathrm{e}-18$ & $1.2509 \mathrm{e}-09$ & $1.2053 \mathrm{e}-06$ & $7.4428 \mathrm{e}-06$ & LSTR \\
\hline$F R$ & 2 & $1.0048 \mathrm{e}-25$ & $1.0872 \mathrm{e}-02$ & $6.4454 \mathrm{e}-09$ & $3.2252 \mathrm{e}-19$ & LSTR \\
\hline$G B$ & 1 & $5.1425 \mathrm{e}-20$ & $3.3655 \mathrm{e}-05$ & $1.6663 \mathrm{e}-09$ & $1.3685 \mathrm{e}-09$ & LSTR \\
\hline$G R$ & 2 & $7.8471 \mathrm{e}-03$ & $2.8558 \mathrm{e}-03$ & $2.9653 \mathrm{e}-01$ & $2.1183 \mathrm{e}-01$ & LSTR \\
\hline$I E$ & 1 & $1.3720 \mathrm{e}-07$ & $3.8773 \mathrm{e}-02$ & $3.5146 \mathrm{e}-01$ & $1.3511 \mathrm{e}-08$ & LSTR \\
\hline$I T$ & 1 & $2.7185 \mathrm{e}-12$ & $4.0051 \mathrm{e}-03$ & $8.0313 \mathrm{e}-04$ & $1.7650 \mathrm{e}-09$ & LSTR \\
\hline$J P$ & 3 & $1.6903 \mathrm{e}-12$ & $6.1898 \mathrm{e}-06$ & $9.8620 \mathrm{e}-02$ & $3.7379 \mathrm{e}-09$ & LSTR \\
\hline$N E$ & 1 & $4.0167 \mathrm{e}-09$ & $2.1965 \mathrm{e}-02$ & $4.8113 \mathrm{e}-04$ & $1.5974 \mathrm{e}-06$ & LSTR \\
\hline$O E$ & 1 & $9.6339 \mathrm{e}-13$ & $2.1666 \mathrm{e}-03$ & $2.2586 \mathrm{e}-06$ & $5.8760 \mathrm{e}-07$ & LSTR \\
\hline$P T$ & 1 & $2.4083 \mathrm{e}-06$ & $1.1981 \mathrm{e}-01$ & $5.7364 \mathrm{e}-02$ & $1.4107 \mathrm{e}-06$ & LSTR \\
\hline$U S$ & 1 & $1.7392 \mathrm{e}-22$ & $3.3094 \mathrm{e}-03$ & $1.4369 \mathrm{e}-09$ & $2.0293 \mathrm{e}-14$ & LSTR \\
\hline \multicolumn{7}{|c|}{ 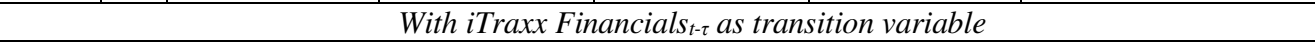 } \\
\hline$B E$ & 2 & $1.1373 \mathrm{e}-07$ & $7.7866 \mathrm{e}-03$ & $8.6915 \mathrm{e}-03$ & $1.0484 \mathrm{e}-05$ & LSTR \\
\hline $\mathrm{CH}$ & 5 & $4.8383 \mathrm{e}-02$ & $5.5120 \mathrm{e}-01$ & $1.1044 \mathrm{e}-01$ & $3.2979 \mathrm{e}-02$ & LSTR \\
\hline$D E$ & 1 & $2.9094 \mathrm{e}-02$ & $2.0937 \mathrm{e}-01$ & $7.1682 \mathrm{e}-01$ & $4.1396 \mathrm{e}-03$ & LSTR \\
\hline$E S$ & 1 & $8.8000 \mathrm{e}-07$ & $1.4460 \mathrm{e}-01$ & $7.1374 \mathrm{e}-04$ & $4.8213 \mathrm{e}-05$ & LSTR \\
\hline$F N$ & 2 & $1.5670 \mathrm{e}-05$ & $5.0277 \mathrm{e}-01$ & $1.4946 \mathrm{e}-02$ & $7.7582 \mathrm{e}-06$ & LSTR \\
\hline$F R$ & 1 & $1.3099 \mathrm{e}-20$ & $1.1504 \mathrm{e}-02$ & $1.3230 \mathrm{e}-02$ & $8.8969 \mathrm{e}-21$ & LSTR \\
\hline$G B$ & 1 & $2.8261 \mathrm{e}-04$ & $7.4330 \mathrm{e}-02$ & $3.1706 \mathrm{e}-01$ & $1.0339 \mathrm{e}-04$ & LSTR \\
\hline$G R$ & 1 & $1.1715 \mathrm{e}-03$ & $9.5175 \mathrm{e}-02$ & $1.2688 \mathrm{e}-01$ & $1.7767 \mathrm{e}-03$ & LSTR \\
\hline$I E$ & 5 & $1.7784 \mathrm{e}-05$ & $1.9348 \mathrm{e}-01$ & $2.9433 \mathrm{e}-05$ & $2.1570 \mathrm{e}-02$ & ESTR / LSTR \\
\hline$I T$ & 1 & $2.0134 \mathrm{e}-17$ & $2.9191 \mathrm{e}-01$ & $4.4812 \mathrm{e}-03$ & $1.1496 \mathrm{e}-18$ & LSTR \\
\hline$J P$ & 4 & $2.6479 \mathrm{e}-02$ & $7.4811 \mathrm{e}-01$ & $1.7539 \mathrm{e}-01$ & $4.0253 \mathrm{e}-03$ & LSTR \\
\hline$N E$ & 5 & $1.5267 \mathrm{e}-07$ & $6.8095 \mathrm{e}-01$ & $5.5065 \mathrm{e}-05$ & $6.3429 \mathrm{e}-06$ & LSTR \\
\hline$O E$ & 1 & $1.7695 \mathrm{e}-03$ & $4.2506 \mathrm{e}-01$ & $8.1614 \mathrm{e}-02$ & $6.5473 \mathrm{e}-04$ & LSTR \\
\hline$P T$ & 1 & $1.6756 \mathrm{e}-10$ & $2.7757 \mathrm{e}-04$ & $1.2638 \mathrm{e}-02$ & $1.5596 \mathrm{e}-07$ & LSTR \\
\hline$U S$ & 1 & $6.0189 \mathrm{e}-25$ & $3.2876 \mathrm{e}-06$ & $7.0427 \mathrm{e}-08$ & $2.0563 \mathrm{e}-15$ & LSTR \\
\hline \multicolumn{7}{|c|}{ With $R_{p, t-\tau}$ as transition variable } \\
\hline$B E$ & 3 & $4.1915 \mathrm{e}-02$ & $4.1663 \mathrm{e}-02$ & $7.8770 \mathrm{e}-01$ & $3.8367 \mathrm{e}-02$ & LSTR \\
\hline $\mathrm{CH}$ & 2 & $6.8721 \mathrm{e}-06$ & $1.1620 \mathrm{e}-03$ & $1.9892 \mathrm{e}-02$ & $3.3202 \mathrm{e}-03$ & LSTR \\
\hline$D E$ & 2 & $1.7641 \mathrm{e}-04$ & $3.5589 \mathrm{e}-01$ & $3.3092 \mathrm{e}-01$ & $6.3251 \mathrm{e}-06$ & LSTR \\
\hline$E S$ & 3 & $8.7913 \mathrm{e}-04$ & $3.1956 \mathrm{e}-01$ & $1.0213 \mathrm{e}-01$ & $3.1367 \mathrm{e}-04$ & LSTR \\
\hline$F N$ & 1 & $1.8168 \mathrm{e}-07$ & $2.4133 \mathrm{e}-02$ & $2.6862 \mathrm{e}-04$ & $1.9115 \mathrm{e}-04$ & LSTR \\
\hline$F R$ & 2 & $1.2795 \mathrm{e}-02$ & $1.8149 \mathrm{e}-02$ & $9.3425 \mathrm{e}-01$ & $9.9224 \mathrm{e}-03$ & LSTR \\
\hline$G B$ & 5 & $7.7347 \mathrm{e}-12$ & $3.6563 \mathrm{e}-01$ & $9.2856 \mathrm{e}-03$ & $9.2733 \mathrm{e}-13$ & LSTR \\
\hline$G R$ & 2 & $1.0027 \mathrm{e}-02$ & $7.2053 \mathrm{e}-03$ & $9.1016 \mathrm{e}-02$ & $4.0247 \mathrm{e}-01$ & LSTR \\
\hline$I E$ & 2 & $1.3889 \mathrm{e}-04$ & $1.0636 \mathrm{e}-02$ & $1.1610 \mathrm{e}-02$ & $1.9192 \mathrm{e}-02$ & LSTR \\
\hline$I T$ & 1 & $4.6555 \mathrm{e}-05$ & $5.9660 \mathrm{e}-02$ & $6.2814 \mathrm{e}-02$ & $1.2259 \mathrm{e}-04$ & LSTR \\
\hline$J P$ & 2 & $5.5265 \mathrm{e}-13$ & $2.4398 \mathrm{e}-04$ & $1.3228 \mathrm{e}-10$ & $2.6472 \mathrm{e}-02$ & ESTR / LSTR \\
\hline$N E$ & 5 & $5.2649 \mathrm{e}-17$ & $5.4507 \mathrm{e}-07$ & $8.1472 \mathrm{e}-07$ & $2.6776 \mathrm{e}-07$ & LSTR \\
\hline$O E$ & 3 & $3.5944 \mathrm{e}-05$ & $2.1514 \mathrm{e}-04$ & $3.8703 \mathrm{e}-03$ & $3.4320 \mathrm{e}-01$ & LSTR \\
\hline$P T$ & 1 & $5.3670 \mathrm{e}-08$ & $2.1082 \mathrm{e}-03$ & $1.9994 \mathrm{e}-05$ & $8.1068 \mathrm{e}-03$ & ESTR / LSTR \\
\hline$U S$ & 1 & $5.4236 \mathrm{e}-34$ & $4.9549 \mathrm{e}-02$ & $2.3171 \mathrm{e}-07$ & $1.2822 \mathrm{e}-30$ & LSTR \\
\hline
\end{tabular}

Note: This table displays the results of the nonlinearity tests based on Eq. (4):

$$
R_{p, t}=\theta_{0}^{\prime} x_{t}+\theta_{1}^{\prime} x_{t} v_{t-\tau}+\theta^{\prime}{ }_{2} x_{t} v_{t-\tau}^{2}+\theta_{3}^{\prime} x_{t} v_{t-\tau}^{3}+\xi_{t}
$$

Where $x_{t}$ is a vector containing the constant and the explanatory variables of equation (2) and where $v_{t-\tau}$ is the transition variable with $\tau$ lags. The chosen lag $\tau$ minimizes the p-value of the nonlinearity test (Teräsvirta, 1994).

Column $\mathrm{H}_{0}$ gives for the selected lag the p-value of the F-test of nonlinearity:

$$
\mathrm{H}_{0}: \theta_{1}^{\prime}=\theta_{2}^{\prime}=\theta_{3}^{\prime}=0
$$

Columns $\mathrm{H}_{04}, \mathrm{H}_{03}$ and $\mathrm{H}_{02}$ give the p-values of the F-tests of the following hypotheses:

$$
\mathrm{H}_{04}: \theta_{3}^{\prime}=0
$$




$$
\begin{aligned}
& \mathrm{H}_{03}: \theta^{\prime}{ }_{2}=0 \mid \theta_{3}{ }_{3}=0 \\
& \mathrm{H}_{02}: \theta_{1}{ }_{1}=0 \mid \theta_{2}=\theta_{3}{ }_{3}=0
\end{aligned}
$$

Following Teräsvirta (1994), if the test of $\mathrm{H}_{03}$ yields the smallest p-value we select an ESTR model, if not we opt for a LSTR model. However this selection rule works best when the number of observations above and below the threshold is about the same. The ESTAR model can indeed be a close substitute to the LSTAR (Teräsvirta, 1994) when most of the observations lie on one side of the estimated threshold value. In this case we estimate a LSTR.

\begin{tabular}{|c|c|c|c|c|c|c|c|c|c|c|c|c|c|c|c|}
\hline & $B E$ & $D E$ & $\mathrm{CH}$ & ES & $F R$ & $F N$ & $G B$ & $G R$ & $I E$ & $I T$ & $J P$ & $N E$ & $P T$ & $O E$ & $\boldsymbol{U S}$ \\
\hline \multicolumn{16}{|c|}{ With VSTOXX $_{\mathrm{t}-\tau}$ as transition variable } \\
\hline \multicolumn{16}{|c|}{ ARCH-LM Test on the residuals of the STR Model } \\
\hline$A R C H(6)$ & $<0.01$ & $<0.01$ & $<0.01$ & $<0.01$ & $<0.01$ & $<0.01$ & $<0.01$ & $<0.01$ & $<0.01$ & $<0.01$ & $<0.01$ & $<0.01$ & $<0.01$ & $<0.01$ & $<0.01$ \\
\hline \multicolumn{16}{|c|}{ Test of no remaining $A R C H$ effect } \\
\hline$A R C H(6)$ & 0.97 & 0.32 & 0.39 & 0.91 & 0.95 & 0.26 & 0.93 & 0.91 & 0.76 & 0.98 & 0.34 & 0.94 & 0.35 & 0.71 & 0.94 \\
\hline \multicolumn{16}{|c|}{ Heteroskedasticity consistent tests of Autocorrelation (AR) and Remaining Nonlinearities (NL) } \\
\hline$A R(6)$ & $>0.99$ & $>0.99$ & $>0.99$ & $>0.99$ & $>0.99$ & $>0.99$ & $>0.99$ & $>0.99$ & $>0.99$ & $>0.99$ & $>0.99$ & $>0.99$ & $>0.99$ & $>0.99$ & $>0.99$ \\
\hline NL & $>0.99$ & $>0.99$ & $>0.99$ & $>0.99$ & $>0.99$ & $>0.99$ & $>0.99$ & $>0.99$ & $>0.99$ & $>0.99$ & $>0.99$ & $>0.99$ & $>0.99$ & $>0.99$ & $>0.99$ \\
\hline \multicolumn{16}{|c|}{ With iTraxx Financials $s_{t-\tau}$ as transition variable } \\
\hline \multicolumn{16}{|c|}{ ARCH-LM Test on the residuals of the STR Model } \\
\hline$A R C H(6)$ & $<0.01$ & $<0.01$ & $<0.01$ & $<0.01$ & $<0.01$ & $<0.01$ & $<0.01$ & $<0.01$ & $<0.01$ & $<0.01$ & $<0.01$ & $<0.01$ & $<0.01$ & $<0.01$ & $<0.01$ \\
\hline \multicolumn{16}{|c|}{ Test of no remaining ARCH effect } \\
\hline$A R C H(6)$ & 0.99 & 0.37 & 0.30 & 0.99 & 0.69 & 0.22 & 0.53 & 0.84 & 0.35 & 0.92 & 0.24 & 0.92 & 0.23 & 0.77 & 0.99 \\
\hline \multicolumn{16}{|c|}{ Heteroskedasticity consistent tests of Autocorrelation (AR) and Remaining Nonlinearities (NL) } \\
\hline$A R(6)$ & $>0.99$ & $>0.99$ & $>0.99$ & $>0.99$ & $>0.99$ & $>0.99$ & $>0.99$ & $>0.99$ & $>0.99$ & $>0.99$ & $>0.99$ & $>0.99$ & $>0.99$ & $>0.99$ & $>0.99$ \\
\hline NL & $>0.99$ & $>0.99$ & $>0.99$ & $>0.99$ & $>0.99$ & $>0.99$ & $>0.99$ & $>0.99$ & $>0.99$ & $>0.99$ & $>0.99$ & $>0.99$ & $>0.99$ & $>0.99$ & $>0.99$ \\
\hline \multicolumn{16}{|c|}{ With $\mathbf{R}_{\mathrm{p}, \mathrm{t}-\tau}$ as transition variable } \\
\hline \multicolumn{16}{|c|}{ ARCH-LM Test on the residuals of the STR Model } \\
\hline$A R C H(6)$ & $<0.01$ & $<0.01$ & $<0.01$ & $<0.01$ & $<0.01$ & $<0.01$ & $<0.01$ & $<0.01$ & $<0.01$ & $<0.01$ & $<0.01$ & $<0.01$ & $<0.01$ & $<0.01$ & $<0.01$ \\
\hline \multicolumn{16}{|c|}{ Test of no remaining $A \mathrm{RCH}$ effect } \\
\hline$A R C H(6)$ & 0.99 & 0.45 & 0.48 & 0.95 & 0.60 & 0.32 & 0.65 & 0.86 & 0.92 & 0.70 & 0.66 & 0.95 & 0.20 & 0.93 & 0.79 \\
\hline \multicolumn{16}{|c|}{ Heteroskedasticity consistent tests of Autocorrelation (AR) and Remaining Nonlinearities (NL) } \\
\hline$A R(6)$ & $>0.99$ & $>0.99$ & $>0.99$ & $>0.99$ & $>0.99$ & $>0.99$ & $>0.99$ & $>0.99$ & $>0.99$ & $>0.99$ & $>0.99$ & $>0.99$ & $>0.99$ & $>0.99$ & $>0.99$ \\
\hline NL & $>0.99$ & $>0.99$ & $>0.99$ & $>0.99$ & $>0.99$ & $>0.99$ & $>0.99$ & $>0.99$ & $>0.99$ & $>0.99$ & $>0.99$ & $>0.99$ & $>0.99$ & $>0.99$ & $>0.99$ \\
\hline
\end{tabular}

Table A3: Results of Misspecification tests ( $p$-values)

Note: This table reports the results from various misspecification tests. The results of the first ARCH-LM test (Engle, 1982) unsurprisingly reject the hypothesis of no conditional heteroskedasticity $(\mathrm{ARCH}(6))$ for all countries. We therefore estimate $\operatorname{GARCH}(p, q)$ models for each country to compute standardized residuals to test for remaining $\mathrm{ARCH}$ effects and we use the heteroskedasticity consistent misspecification tests statistics proposed by van Dijk et al. (2002). 